DANIEL KALANSKY PONCZEK

DIREITO DE RECESSO E VALOR JUSTO COMO PROTEÇÃO DO INVESTIDOR: A REFORMA NECESSÁRIA

TESE DE DOUTORADO

Orientador: Professor Associado Haroldo Malheiros Duclerc Verçosa

UNIVERSIDADE DE SÃO PAULO

FACULDADE DE DIREITO

SÃO PAULO - SP

2020 


\title{
DIREITO DE RECESSO E VALOR JUSTO COMO PROTEÇÃO DO INVESTIDOR: A REFORMA NECESSÁRIA
}

\author{
Tese de Doutorado submetida à Banca \\ Examinadora do Programa de Pós- \\ Graduação em Direito da Faculdade de \\ Direito da Universidade de São Paulo, \\ como requisito parcial para a obtenção do \\ título de Doutor em Direito na área de \\ concentração Direito Comercial, sob a \\ orientação do Professor Associado \\ Haroldo Malheiros Duclerc Verçosa.
}

\section{UNIVERSIDADE DE SÃO PAULO}

FACULDADE DE DIREITO

SÃO PAULO - SP

2020 


\section{Catalogação na Publicação}

Serviço de Processos Técnicos da Biblioteca da

Faculdade de Direito da Universidade de São Paulo

\section{Kalansky, Daniel}

O Direito de Recesso e Valor Justo como Proteção do Investidor: A Reforma Necessária / Daniel Kalansky - São Paulo, 2020.

Tese (Doutorado) - Programa de Pós-Graduação em Direito. Faculdade de Direito, Universidade de São Paulo, São Paulo, 2020.

Orientador: Haroldo Malheiros Duclerc Verçosa

1. Direito de Recesso na Sociedade Anônima. 2. Valor Justo. 3. Proteção do acionista minoritário. 4. Critérios de Avaliação. 5. Reforma da Lei das S.A. I. Verçosa, Haroldo Malheiros Duclerc, orient. II. Título 
Cuando creíamos tener todas las respuestas, de pronto se cambiaron las preguntas

(Mario Benedetti) 


\section{AGRADECIMENTOS}

Ao Professor Haroldo Verçosa, por ter aceitado me orientar, desde o meu mestrado até o doutorado. Foi um professor que confiou na minha capacidade acadêmica e pôde contribuir de forma muito produtiva em todas as belíssimas discussões que tivemos, em grande parte dos temas do direito comercial. Sempre uma alegria enorme poder tomar um café no seu prazeroso home office.

Aos Professores José Alexandre Tavares Guerreiro e Francisco Satiro, por sempre ajudarem a nos orientarmos nos grandes temas de direito societário. Graças a suas boas iniciativas, passamos uma semana na Columbia University, em New York, oportunidade em que tivemos aulas bem proveitosas com excelentes professores. Foi possível discutir importantes temas do direito societário, principalmente sobre appraisal rights e class actions. Foi uma oportunidade única de conversar e ter um intercâmbio acadêmico com os professores Joshua Mitts e Merrit B. Fox.

Foi a aula do professor Joshua Mitts, com base no seu texto Asking the right question: the Statutory Right of Appraisal and Efficient Markets, escrito em coautoria com o professor Jonathan Macey, que me fez refletir sobre o tema do valor do recesso no direito brasileiro e produzir a presente tese. Não tive outra escolha senão, depois dessas aulas, mudar meu tema, cujo desenvolvimento já estava na sua metade, para tratar desse assunto que despertou curiosidade, vontade e dúvidas - três características fundamentais para produzir um trabalho de doutorado. Devo agradecer ao meu orientador, que concordou com a alteração, permitindo tratar desse tema que tanto despertava curiosidade. O outro tema, que estava pela metade, quem sabe não virá em um pósdoutorado.

Agradeço também ao meu sócio Eli Loria, que, com sua grande experiência e anos na Comissão de Valores Mobiliários, permitiu que a sua prática ajudasse na reflexão sobre tema. Foi um grande incentivador para cursar o doutorado. Disse a ele que, com quatro filhos, seria impossível, mas ele me deu as dicas e os caminhos para essa empreitada.

Não poderia também deixar de mencionar a minha colega de escritório Nadja Nogueira, que me ajudou bastante nas discussões. Sua vontade de discutir temas novos fez que nossos debates chegassem a boas conclusões. É impressionante sua curiosidade 
pelo direito societário, que, com perguntas instigantes, fez o trabalho se refinar cada vez mais.

A minha família e principalmente minha esposa, Tamara. Apesar de ela ser decoradora de interiores, eu pedia sua ajuda para ler alguns artigos da Lei das S.A. em que estava com dúvidas. Certamente fez porque gosta de mim, uma vez que decorar apartamentos deve ser muito mais interessante que discutir direito de recesso. Agradeço também a meus pais, Jaime e Doris, que sempre incentivaram os estudos. $\mathrm{O}$ fato de o meu pai ser contador ajudou bastante nas minhas discussões sobre critérios de avaliação no direito de recesso.

E, por fim, aos meus filhos, Rafael, Sharon, Mauricio e Rony, que sempre me perguntavam se já tinha terminado o doutorado, quando ainda estava no seu começo. Pelo menos estão crescendo sabendo o que é um doutorado, e, melhor ainda, o conceito de esforço. 


\section{RESUMO}

Kalansky, Daniel. Direito de Recesso e Valor Justo como Proteção do Investidor: A Reforma Necessária (233 p.). Tese de Doutorado em Direito Comercial: Faculdade de Direito da Universidade de São Paulo, São Paulo, 2020.

Este trabalho parte da seguinte indagação: qual seria o melhor critério de avaliação para calcular o reembolso para fins de recesso do acionista minoritário dissidente de uma sociedade por ações?

A análise partiu da constatação de que a atual Lei das Sociedades por Ações (Lei n 6.404 de 1976), conforme entendimento majoritário, fixa como método de cálculo o patrimônio líquido contábil, quando o estatuto social não determina que outro seja aplicado. Contudo o método nem sempre reflete o valor justo da companhia, o que faz com que ao acionista seja ofertado um valor irrisório.

Para estudar esse tema, começou-se por analisar a origem e os propósitos para os quais o recesso foi criado. Em seguida, analisaram-se os métodos de cálculo disponíveis para avaliar uma companhia. Estudou-se, também, a maneira como o reembolso é calculado nos Estados Unidos da América e na Itália. Com esse arcabouço teórico, analisou-se o direito brasileiro e, ao final, delineou-se como seria o valor de reembolso ideal.

Concluímos pela necessidade de uma reforma legislativa de forma a prever que o valor do recesso deve dar-se obrigatoriamente pelo valor justo e, assim, oferecer proteção ao acionista minoritário e fomentar o mercado de capitais.

Palavras-chave: Direito de Recesso. Direito de Retirada. Reembolso. Direito Essencial do Acionista. Sociedade Anônima. Valor Justo. Proteção do acionista minoritário. Critérios de Avaliação. 


\begin{abstract}
Kalansky, Daniel. Appraisal Right and Fair Value as Investor Protection: The Needed Reform (233 p). Doctorate Thesis: School of Law, University of São Paulo, São Paulo, 2020.
\end{abstract}

This thesis focuses on the following question: what would be the best valuation method to determine the value the shares of a company in an appraisal procedure?

The current Brazilian Corporate Law (Law n 6.404 of 1976) sets the book value as the standard method to define the share value. Companies may adopt a different method in their corporate contract; however, few have done so. This method does not reflect the company's inherent value, which means that the shareholder is not offered a fair value.

To answer this question, we started by analyzing the origin and the purposes for which the appraisal right was created. Then, the valuations methods available to appraise a company were analyzed. We also studied how the value of the shares is calculated in the United States of America and Italy. With this theoretical framework, Brazilian law was analyzed and, at the end, what the ideal reimbursement value would be was outlined.

We concluded that an amendment in our Corporate Law is essential to establish the fair value as a mandatory rule to obtain the payment for the dissenting shareholder for the purposes of protection for the minority shareholders and to foster the capital market.

Keywords: Appraisal Right. Appraisal Remedy. Right to Dissent. Reimbursement. Essential Right of the Shareholder. Corporate Law. Fair Value. Protection for the Minority Shareholders. Valuation Methods. 


\section{RIASSUNTO}

Kalansky, Daniel. Diritto di Recesso e Valore Equo come Protezione degli Investitori: La Riforma Necessaria (233 p.). Tesi di Dottorato: Facoltà di Giurisprudenza, Università di São Paulo, São Paulo, 2020.

Questa tesi si concentra sulla seguente domanda: quale sarebbe il modo migliore per valutare le azioni di una società in una procedura di valutazione?

L'attuale legge societaria brasiliana (legge n. 6.404 del 1976) fissa il patrimonio netto come metodo di valutazione delle azioni. Le società possono adottare un metodo diverso nel loro contratto aziendale; tuttavia, pochi l'hanno fatto. Questo metodo non riflette il valore intrinseco della società, il che significa che all'azionista viene offerto un importo trascurabile.

Per rispondere a questa domanda, abbiamo iniziato analizzando l'origine e gli scopi per i quali è stato creato il diritto di valutazione. Quindi, sono stati analizzati i metodi di valutazione disponibili per valutare una società. Abbiamo anche studiato come viene calcolato l'importo del rimborso negli Stati Uniti d'America e in Italia. Con questo quadro teorico, la legge brasiliana è stata analizzata e, alla fine, è stato delineato il valore di rimborso ideale.

Concludiamo che è necessaria una riforma legislativa per prevedere che il valore della rientranza debba essere dato al valore equo come un modo per proteggere gli azionisti di minoranza e promuovere il mercato dei capitali.

Parole chiave: Diritto di recesso. Rimborso. Legge essenziale per gli azionisti. Società per azioni. Valore equo. Protezione degli azionisti di minoranza. Metodi di Valutazione. 


\section{SUMÁRIO}

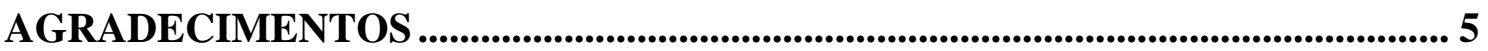

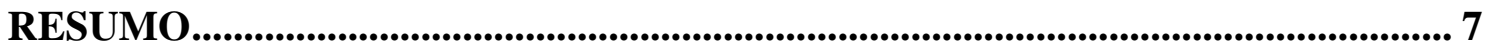

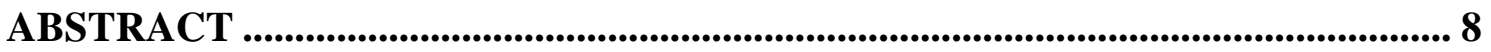

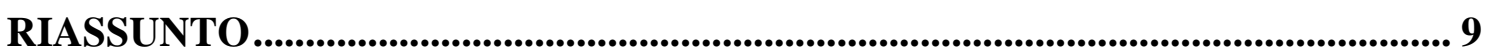

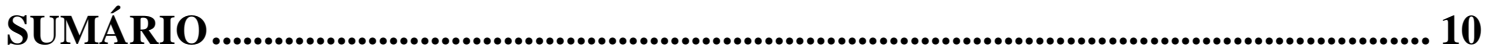

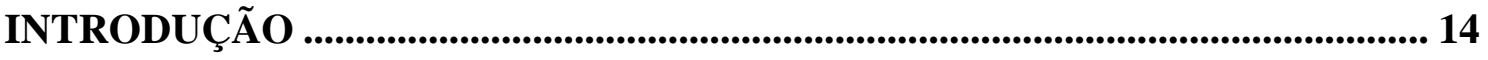

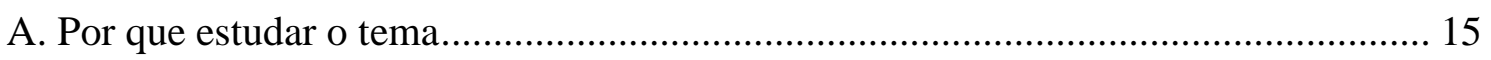

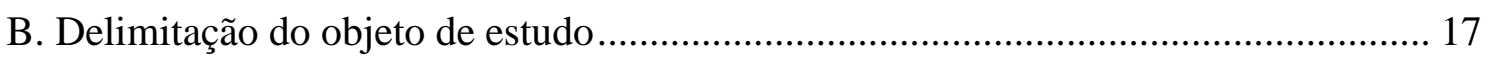

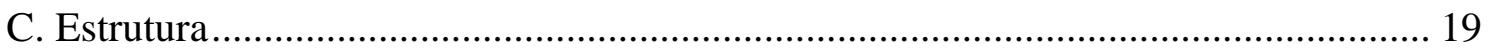

D. Por que o cálculo do valor do recesso é tão importante …......................................... 20

CAPÍtUlo 1 - DIREITO de RECESSO E A PROTEÇÃo AO ACIONISTA

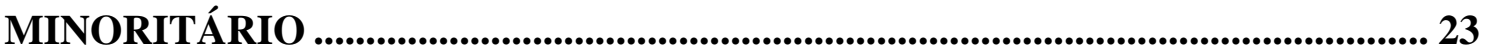

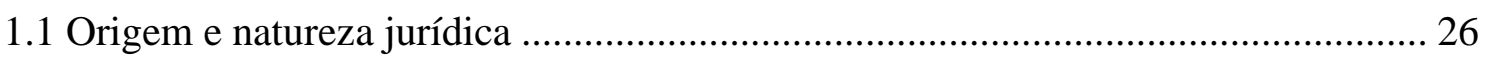

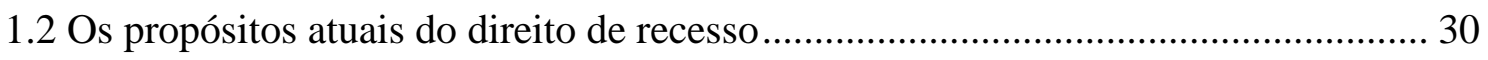

1.2.1 Proteção do acionista minoritário ..................................................... 30

1.2.2 Proteção da continuidade da sociedade ........................................... 32

1.2.3 Solução dos problemas de agência .................................................. 34

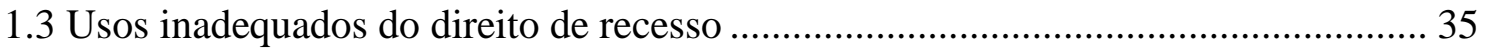

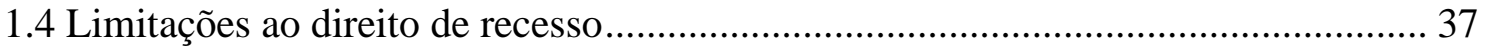

CAPÍTULO 2 - CRITÉRIOS E MÉTODOS DE AVALIAÇÃO DE EMPRESAS 41

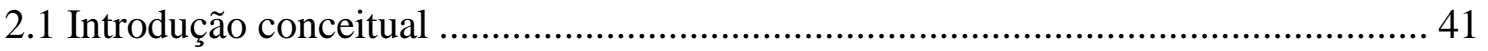

2.1.1 Introdução à relação entre Contabilidade e Direito ........................... 42

2.1.2 A diferença entre valor e preço.................................................... 45

2.1.3 A definição de "fair value". ....................................................... 47

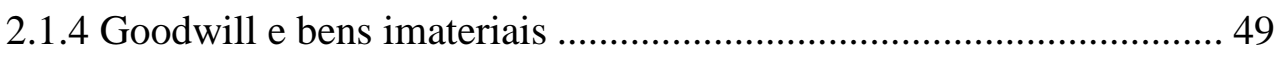

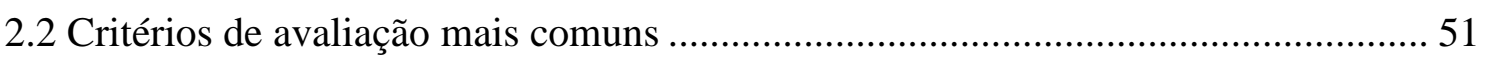

2.2.1 Critérios de Avaliação do Patrimônio.............................................. 52

a) Patrimônio Líquido ........................................................................ 52 
b) Patrimônio Líquido a Preço de Mercado............................................. 54

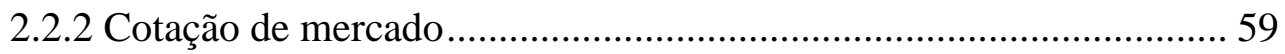

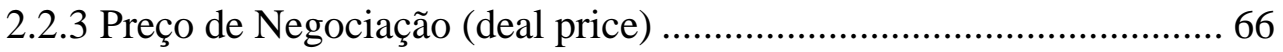

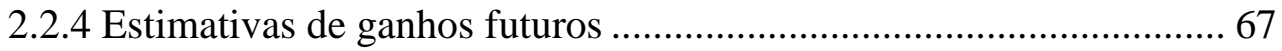

2.2.5 Comparação por múltiplos........................................................ 70

2.3 Quais métodos poderiam ser utilizados para efeito de reembolso? .......................... 72

CAPÍtUlo 3 - COMO FUNCIONA O CÁlCULO DO VALOR DE REEMBOLSO NO DIREITO AMERICANO E ITALIANO................................... 75

3.1 Direito de recesso nos Estados Unidos da América ................................................. 75

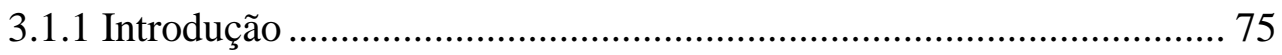

3.1.1.1 Inconsistência das hipóteses de recesso................................ 77

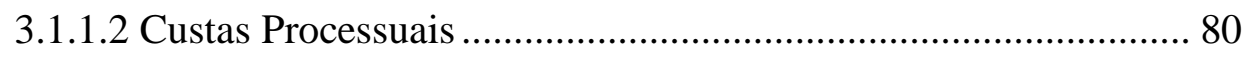

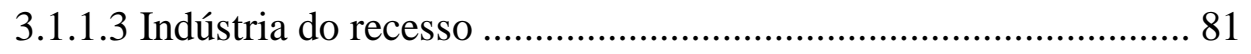

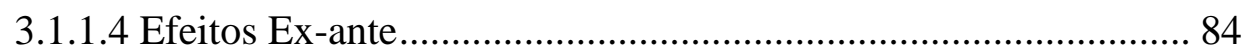

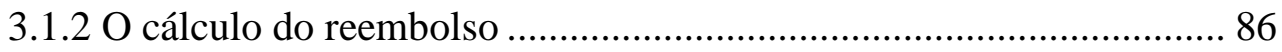

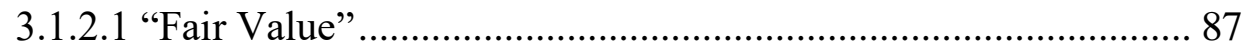

3.1.2.1.1 Tri-Continental Corp. v. Battye ....................................... 90

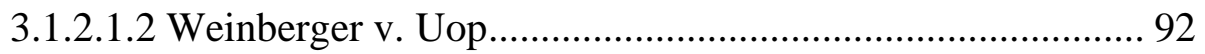

3.1.2.1.3 DFC Global v. Muirfield Value Partners............................. 94

3.1.2.1.4 Dell Inc. v. Magnetar Global Event Driven Master Fund Ltd 97

3.1.2.1.5 Blueblade Capital Opportunities, L.P v. Norcraft Inc. ...... 102

3.1.2.1.6 Verition Partners Master Fund Ltd. v. Aruba Networks, Inc. 104

3.1.2.1.7 In Re Appraisal of Solera Holdings, Inc.......................... 108

3.1.2.1.8 In Re Appraisal of Jarden Corporation ............................. 110

3.1.2.1.9 In Re Appraisal of Columbia Pipeline Group, Inc. ........... 114

3.1.2.1.10 In Re Appraisal of Stillwater Mining Company .............. 116 


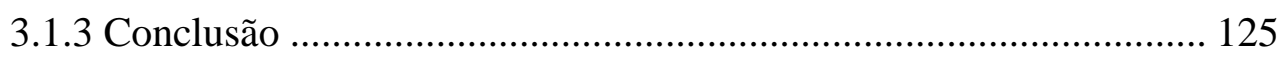

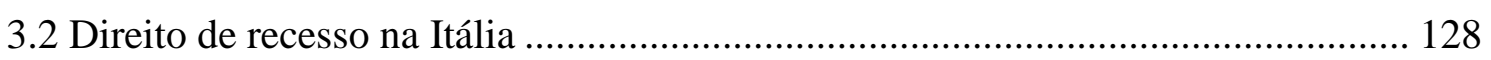

3.2.1 Introdução ao Direito de Recesso na Itália ......................................... 128

3.2.2 Evolução da Legislação .................................................................. 130

3.2.3 O cálculo do reembolso na Itália .................................................... 135

3.2.3.1 A lei é assertiva e inflexível quanto aos critérios a serem aplicados para sociedades cotadas no mercado. 135

3.2.3.2 A avaliação das ações não cotadas é mais flexível e adaptável ao caso concreto 139

3.2.3.3 $\mathrm{O}$ procedimento foi modificado para atender às necessidades dos acionistas dissidentes e da companhia sobrevivente 143

CAPÍTULO 4 - O REEMBOLSO NO BRASIL ................................................... 145

4.1 Evolução legislativa em relação ao valor do reembolso........................................... 145

4.2 Entendimento doutrinário quanto ao valor do recesso .......................................... 151

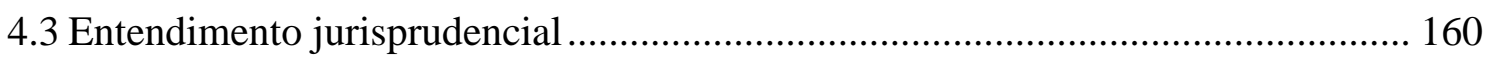

4.3.1 Banco Independência Decred de Investimentos ................................ 160

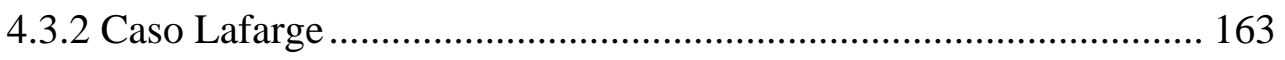

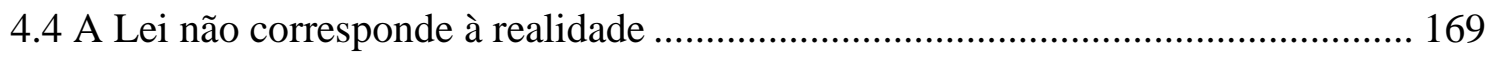

CAPÍTULO 5 - PROPOSTA DE MODIFICAÇÃO.................................................. 174

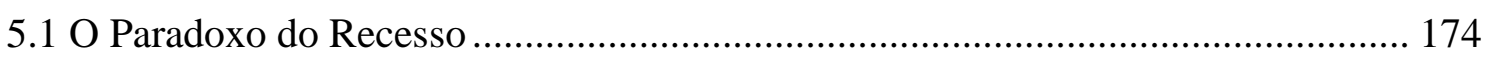

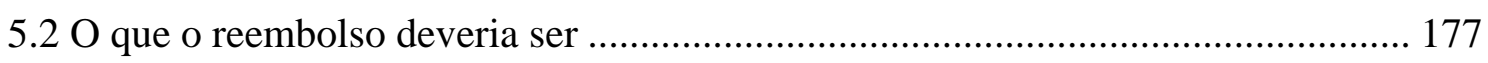

5.2.1 Mudanças necessárias ................................................................... 177

5.2.1.1 Critério Mandatório ............................................................... 177

5.2.1.2 O valor das ações não deve ser calculado com base em um só critério de avaliação..................................................................................... 180

5.2.1.3 Oportunidade de contestação do acionista minoritário.............. 185

5.2.2 $\mathrm{O}$ que deve permanecer................................................................. 186 
5.2.2.2 Comunicação do valor na convocação da Assembleia Geral ... 188

5.2.3 Falácia do Nirvana ................................................................. 189

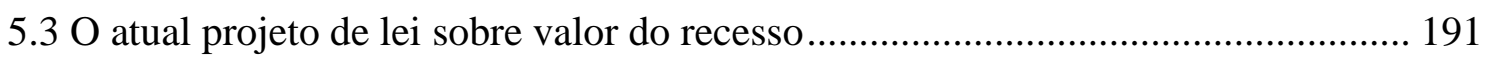

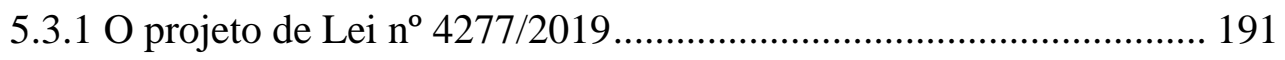

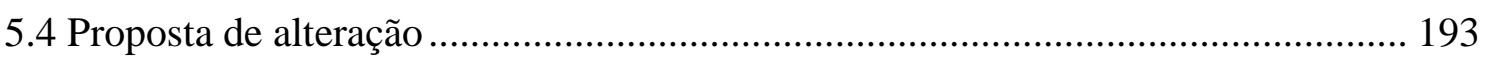

5.4.1 O procedimento do cancelamento de registro do art. $4^{\circ}$ e art. $4^{\circ}-\mathrm{A} .193$

5.4.2 Definição da expressão "valor justo" ............................................ 196

5.4.3 Razões pelas quais o sistema do art. $4^{\circ}, \S 4^{\circ}$, deveria ser adotado para o

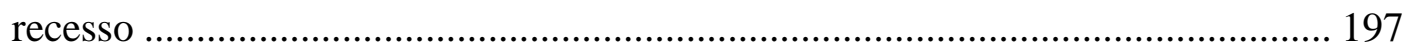

5.4.4 Possíveis críticas ........................................................................ 199

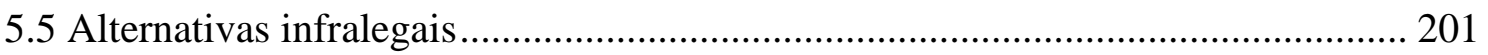

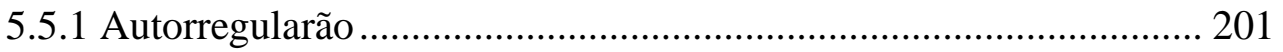

5.5.2 Princípio do "aplique ou explique" e a "soft law".......................... 203

CONCLUSÃO

A. Qual a definição e os propósitos do recesso? ............................................................ 207

B. Por que o recesso permanece relevante hoje?.................................................... 208

C. Quais os critérios de cálculo disponíveis e qual o melhor para efeitos do exercício do

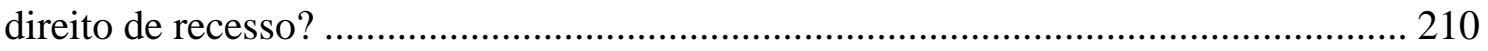

D. O que pode ser aprendido com o direito americano e quais as principais falhas?... 212

E. O que pode ser aprendido com o direito italiano e quais as principais falhas? ....... 213

F. Quais falhas podem ser observadas na legislação atual? ..................................... 215

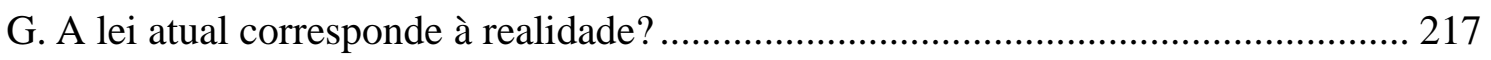

H. O recesso pelo valor justo pode inviabilizar operações? ...................................... 218

I. Qual é a proposta de reforma proposta para o direito de recesso? ......................... 219

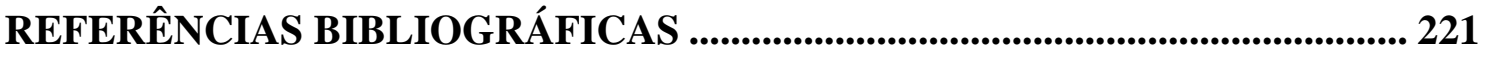




\section{INTRODUÇÃO}

Imagine-se uma operação em que uma companhia aberta brasileira, sem liquidez ou dispersão acionária, anuncia que fará a incorporação de outra com as mesmas características.

Na operação, caberá recesso para os acionistas da companhia alvo. No protocolo e justificação da operação, foi anunciado o valor da ação para efeito de reembolso seria de $\mathbf{R} \$ \mathbf{1 0 , 0 0}$, calculado a partir do patrimônio líquido, ou seja, o proporcional do acionista dos ativos subtraídos dos passivos. Esse valor reflete apenas o patrimônio da companhia, não levando em consideração a capacidade de produção da companhia ou de gerar renda, o seu goodwill, nem o valor negociação das ações na bolsa de valores.

Para efeitos de comparação, nos 90 dias anteriores ao anúncio da operação, a média do valor de cotação das ações da companhia incorporada havia sido $\mathbf{R} \mathbf{\mathbf { 2 0 , 0 0 }}$ por ação. Com o anúncio da operação, as ações de emissão da companhia incorporada foram desvalorizadas e passaram a ser negociadas na bolsa no valor de $\mathbf{R} \$ \mathbf{1 5 , 0 0}$.

Por conta da operação, um laudo de avaliação foi preparado por empresa especializada, de acordo o método de fluxo de caixa descontado e o valor da ação, para efeito de relação de troca, foi determinado em $\mathbf{R} \$ \mathbf{3 0 , 0 0}$. Em paralelo, uma avaliação pelo critério de comparação por múltiplos também foi realizada, estimando o valor da companhia em $\mathbf{R} \mathbf{2 5 , 0 0}$ por ação.

Observa-se uma multiplicidade de valores para uma mesma ação. Nenhum deles está errado, pois todos foram adequadamente calculados segundo os métodos de avaliação que consideram aspectos diferentes de uma companhia. Eles representam perspectivas diferentes da mesma empresa e possuem utilidades diferentes para os administradores, acionistas e juristas. Porém aos acionistas dissidentes, a disposição legal atual permite que a companhia ofereça o valor patrimonial $(\mathbf{R} \$ \mathbf{1 0 , 0 0})$, não importa o quão distante ele seja do valor justo da companhia, caso outra forma não tenha sido prevista no estatuto social.

Diante desse cenário, o acionista dissidente tem que fazer uma escolha: sair da companhia e receber um valor que não representa o quanto ela realmente vale, ou permanecer na companhia e aceitar a nova conjuntura, a qual não quer fazer parte, pois as bases do investimento foram totalmente alteradas. 
Observando cenários como esse, em que o acionista minoritário fica confinado a escolher entre duas opções em que sofre perdas, o presente trabalho assenta-se na hipótese de que há muito a discutir sobre o valor do reembolso no exercício do direito de recesso, principalmente, se o Brasil deve adotar como critério mandatório para o reembolso o valor justo e quais seriam as possíveis repercussões positivas e negativas de sua adoção.

A pergunta que se busca responder no presente trabalho é: qual valor o acionista dissidente deveria receber para efeito de reembolso dentre as possíveis formas de se avaliar uma companhia? Deve-se predeterminar um critério legal mandatório ou deixar a cargo do estatuto social determinar o valor do reembolso?

Buscar-se-á demonstrar a necessidade de atualização do texto legal para proteger o investimento do acionista minoritário ou, pelo menos, fazer com que a administração também considere seus interesses. Por fim, propor-se-á qual deveria ser o conteúdo desta modificação, com base no que foi estudado.

\section{A. POR QUE ESTUDAR O TEMA}

Apresentam-se duas razões para estudar o tema.

A primeira delas é que o recesso é um mecanismo de proteção ao acionista minoritário que depende apenas de sua vontade para ser acionado, mas é raramente utilizado, tendo em vista a escassa jurisprudência sobre o assunto

Poder-se-ia supor que os acionistas minoritários não sabem de sua existência. Contudo não parece ser uma hipótese plausível. A convocação para assembleias gerais cujo tema enseja recesso já contém disposição sobre a possibilidade de exercê-lo e o valor das ações segundo o critério legal - patrimônio líquido - ou conforme o que estiver previsto no estatuto social. Assim, é justo supor que os acionistas estão cientes de que podem exercer o recesso.

Também poderia se pensar que a maioria das companhias com ações negociadas na bolsa possui liquidez e dispersão de forma que não haveria que se falar de recesso na medida em que o acionista dissidente poderia vender suas ações na bolsa caso discordasse da deliberação tomada pela maioria dos acionistas. Porém a maioria das companhias com ações negociadas na bolsa não atende ao referido critério. 
Com base nas informações da B3, em 31 de dezembro de 2019, havia 391 companhias com ações listadas na B3, sendo que, verificando o último trimestre daquele ano, 68 delas integravam o IBOVESPA. Dessa forma, somente cerca de 17,39\% das companhias abertas atenderia ao requisito de liquidez previsto no Art. 137, II, "a", da Lei das S.A. Dessas 68 companhias que integravam o IBOVESPA, 42 naquele trimestre apresentavam a dispersão prevista no Art. 137, II, "a", da Lei das S.A. Em suma, a previsão do Art. 137, II, da Lei das S.A., além de limitada a somente dois incisos do artigo 136 (fusão da companhia, ou sua incorporação em outra, e participação em grupo de sociedades), seria aplicada a apenas aproximadamente $10,74 \%$ das companhias cujas ações estavam listadas na $\mathrm{B3}$ no último trimestre de 2019. Isso demonstra o quanto o direito e o valor do recesso são importantes, porque a saída pelo mercado (market out exception) alcança uma parcela muito pequena das companhias listadas ${ }^{1}$.

Alternativamente, poder-se-ia supor, simplesmente, que o recesso "não vale a pena", isto é, ele não é uma opção concreta para o acionista. Por conta do método de cálculo ofertado pela lei, o valor de reembolso das ações é, frequentemente, irrisório, como demonstrado no exemplo acima. O patrimônio líquido não reflete o investimento feito pelo acionista minoritário, apenas os ativos da companhia subtraídos dos seus passivos.

Além disso, o recesso acaba não gerando influência sobre a administração e o acionista ou grupo majoritário agem sem mesmo considerar a possibilidade de que algum minoritário queira exercer o recesso, pois o valor do reembolso será, provavelmente, muito pequeno.

Assim, o dissidente pode até conseguir sair da companhia antes que a nova configuração se estabeleça, contudo será prejudicado de qualquer forma. É uma situação de "ganha, mas não leva".

Em verdade, chegou-se à conclusão, durante as pesquisas, de que o único efeito prático do recesso é a extinção do status socii e o empobrecimento do acionista dissidente. Ele não afeta o planejamento da companhia e seu valor não reflete a realidade da companhia.

\footnotetext{
${ }^{1}$ Solicitação de informações realizada junto a B3, por meio de seu setor de Regulação, Orientação e Enforcement de Emissores em maio de 2020.
} 
A segunda razão para estudar esse assunto é que ele é pouco discutido no Brasil, porém tem se tornado tendência de debates acalorados em outras jurisdições. Abordaramse dois países que fortemente influenciam o direito brasileiro: Estados Unidos da América e Itália. O primeiro porque é onde as grandes discussões jurisprudenciais sobre o assunto são realizadas e o segundo porque é o berço das concepções usadas no Brasil de direito comercial.

Nos Estados Unidos, observou-se nos últimos cinco anos que o direito de recesso se tornou mais frequente. Vinte anos atrás, ele era uma raridade e, porém, contatou-se um aumento no número de recessos e no volume requerido. Essa tendência produziu julgamentos detalhados que abordam do propósito do recesso à discussão de qual seria o critério de avaliação ideal, além de vasta bibliografia acadêmica ${ }^{2}$.

Já na Itália, o direito de recesso foi, em uma reforma apenas, de extremamente restritivo para permissivo. Uma profunda reforma realizada em $2003^{3}$ aumentou o número de hipóteses do recesso e adotou, para determinar o valor do reembolso, o valor cotado na bolsa, para companhias abertas, e uma combinação de referenciais a ser escolhida pela administração, para companhias fechadas.

Assim, é razoável ponderar sobre como o reembolso para fins de recesso é feito no Brasil. Do ponto de vista acadêmico, deve-se atentar para as tendências internacionais e questionar se é necessário adequar a regulamentação para proteger o acionista minoritário, ou se a atual já atinge esses efeitos, inclusive para atrair os investidores no nosso mercado de capitais.

\section{B. DELIMITAÇÃO DO OBJETO DE ESTUDO}

O foco principal deste trabalho é estudar a seguinte hipótese: seria o método de cálculo do reembolso adotado na legislação brasileira o mais adequado a produzir os efeitos planejados para o recesso?

\footnotetext{
2 SIEGEL, Mary. Back to the future: Appraisal Rights in the twenty-first century. Harvard Journal on Legislation, Cambridge, EUA, v. 01, n. 32, p.79-143, 1995. Pg. 89.

${ }^{3}$ REPÚBLICA ITALIANA. Decretos legislativos n ${ }^{\circ} 5$ e 6 de 17 de janeiro de 2003. Reforma do Direito Societário no Código Civil Italiano.
} 
Discutir-se-á qual o método de avaliação adequado para fins de reembolso e as perguntas que partem desse raciocínio.

Não se discutirá a pertinência do recesso, ou o raciocínio por trás da escolha das hipóteses. Por mais que a análise da doutrina sobre o direito de recesso seja parte do trabalho ora desenvolvido, adotou-se que o direito é parte da legislação brasileira, e não se ponderou sobre a pertinência de sua inclusão. Isto é, o direito de recesso existe; se deveria existir é assunto para outro trabalho. O trabalho teve como foco a análise do valor do reembolso para fins de recesso em sociedades anônimas abertas.

Para encontrar a resposta à questão principal, foi necessário abordar algumas perguntas acessórias. Selecionaram-se três.

A primeira delas é a própria definição de recesso. O critério de cálculo faz parte da execução e efetividade desse direito, como um acessório a sua existência. Assim, abordaram-se as circunstâncias que levaram à criação do direito de recesso e sua popularização em vários contextos diferentes. Estudou-se, também, o que faz do recesso uma ferramenta relevante hoje, isto é, quais os propósitos que a doutrina e a jurisprudência apontam para justificar a continuidade da existência do recesso.

No mesmo sentido, também se estudou como outros países adotam e aplicam o direito de recesso, levando em consideração seus respectivos mercados de capitais e tradição empresarial.

A segunda pergunta é: quais métodos de avaliar uma companhia existem e quais informações cada um deles presta ao investidor? Para ponderar sobre a melhor adequação de um método de avaliação específico, foi necessário conhecer cada um deles, os critérios que utilizam e qual uso lhes é dado do ponto de vista contábil e financeiro.

Por fim, foi necessário questionar qual seria o formato ideal do recesso para atingir os fins que lhe foram atribuídos, isto é, estudar o recesso como meio, e várias perguntas surgiram, como estas: o legislador deveria fixar apenas um método de avaliação ou oferecer um leque de opções para a administração escolher, ou melhor, deixar a cargo do estatuto social estabelecer o valor de recesso? Deveria haver mais formas de o acionista minoritário de questionar o valor adotado para efeitos de recesso? Seria justo com a companhia ter de arcar com um valor de reembolso que excedesse o valor estabelecido na relação de troca, em uma determinada incorporação? Ou o contrário, o acionista receber um valor que fosse muito abaixo do valor da negociação? 


\section{ESTRUTURA}

Para responder a essas perguntas, dividiu-se a tese em cinco capítulos, mais um, para a Conclusão. Os três primeiros são dedicados a estabelecer as premissas necessárias para abordar a questão principal e os dois últimos ponderam sobre o recesso no Brasil, o que seria o recesso ideal e a proposta de reforma legislativa proposta. Por fim, a Conclusão sintetiza e responde os pontos centrais do trabalho.

Em termos mais esparsos, no Capítulo 1, trabalhou-se com a definição do recesso. Buscou-se demonstrar como surgiu o direito de recesso e como ele chegou ao Brasil, bem como suas limitações. O foco principal do capítulo é desvendar os propósitos que o direito de recesso deve observar e como o meio eleito, o reembolso, pode atendê-los.

No Capítulo 2 estão expostos os métodos de avaliação de empresas a serviço do direito societário. O foco do capítulo é estudar quais variáveis são consideradas para cada um dos métodos e quais informações fornecem. O ponto principal a ser demonstrado no capítulo é que cada um dos critérios de avaliação possui um propósito diferente. São ferramentas que atendem a necessidades diferentes, as quais nem sempre correspondem às necessidades que o ordenamento planeja para elas.

No Capítulo 3, analisaram-se os esforços feitos pela academia e pelo judiciário estrangeiro para responder a esses mesmos questionamentos que se propõe para este trabalho. O foco é compreender se as soluções que os italianos e americanos encontraram são adequadas, ou não, para seus próprios ordenamentos e quais são os efeitos dessa regulamentação sobre a atividade empresarial.

Com esses conceitos em mente, o Capítulo 4 tem por foco analisar as falhas contidas na lei brasileira. Discute-se como o mecanismo adotado na Lei das S.A. deixa o investidor vulnerável às decisões da maioria, sejam elas em seu interesse ou não. $\mathrm{O}$ objetivo do texto é demonstrar que existem falhas lógicas na lei e imprecisão textual, que, em conjunto, geram insegurança jurídica sobre qual método de cálculo aplicar ao cálculo do reembolso para fins de recesso.

No Capítulo 5, discute-se a pertinência de uma reforma legislativa para corrigir as falhas encontradas no Capítulo anterior. O propósito do Capítulo foi apresentar uma 
alternativa para a legislação em vigor que permitiria proteger o investidor e fomentar o mercado de capitais, ao mesmo tempo.

Por fim, na Conclusão, sintetizam-se as informações mais importantes e aprofundam-se os raciocínios e conclusões centrais deste trabalho. Entendeu-se que o valor justo deveria ser o critério para o cálculo do reembolso, pois não é um método de cálculo fixo, mas uma metodologia para avaliar a qualidade de cada uma das avaliações da companhia e constatar qual delas representa a companhia de maneira mais fidedigna em um momento específico. Seria necessário, portanto, modificar o art. 45 da Lei das S/A, apresentando-se uma proposta de reforma.

\section{POR QUE O CÁlCULO dO VALOR dO RECESSO É TÃo IMPORTANTE}

Em uma primeira impressão, o valor de reembolso pode parecer uma questão acessória ao estudo do direito de recesso. Porém, argumenta-se que, em verdade, ele é central. Durante a elaboração da presente tese, percebeu-se que o potencial do recesso de promover equidade está intrinsicamente ligado ao cálculo do valor das ações.

Bayless Manning ${ }^{4}$ menciona que a maneira como o direito de recesso vinha sendo estudado focava-se demasiadamente na discussão sobre conceito do recesso e, por conta disso, a academia não conseguia apontar uma evolução para atender as necessidades pragmáticas dos agentes econômicos, por conseguinte, o recesso permanecia virtualmente inútil para os acionistas.

Em outras palavras, Manning defende que um remédio conceitualmente sólido, mas que não surte efeito algum, certamente não será usado.

Entende-se que essa observação também se aplica ao Brasil. O direito de recesso é oferecido como compensação pela derrogação de um princípio contratual (unanimidade) $^{5}$, porém não é atrativo para o acionista minoritário, de forma que é

\footnotetext{
4 “[...] Historically, we got off on the remedial route of appraisal only because of ideological problems problems that have largely disappeared. We never have tried to use it to help solve economic problems of the enterprise. Shareholders have been cheerfully carrying all kinds of real economic risks without the benefit of appraisal." MANNING, Bayless. The shareholder's appraisal remedy: An essay for Frank Coker. The Yale Law Journal, New Haven, v. 72, n. 2, p. 224-264, dez. 1962. p. 261.

${ }^{5}$ SZTAJN, Rachel. Direito de Recesso. 1982. 312 f. Tese (Doutorado) - Curso de Direito, Departamento de Direito Comercial, Universidade de São Paulo, São Paulo, 1982. p. 14 e 15.
} 
raramente utilizado. Com base nesse raciocínio, o direito de recesso oferece pouca ou nenhuma melhoria das condições de investimento ou posição negocial dos acionistas minoritários.

Poder-se-ia sustentar que, nos Estados Unidos, o direito de recesso também é pouco utilizado ${ }^{6}$, a despeito dos esforços feitos pela academia. Contudo os fatores que interferem na difusão do uso do direito de recesso são diferentes. O processo para obter o direito de recesso nos Estados Unidos perpassa necessariamente pelo judiciário, o que o torna excessivamente caro. Economicamente falando, mesmo que o autor do pedido de recesso receba o "valor justo", terá que arcar com gastos processuais, fato que o torna inviável em algumas situações. Ainda assim, nos últimos cinco anos, tem crescido bastante nos Estados Unidos a utilização do direto de recesso pelos acionistas minoritários ${ }^{7}$.

No Brasil, o exercício do recesso permanece um evento incomum. Cumpre, pois, analisar de que maneira o cálculo do valor do reembolso inibe a saída do acionista por meio do recesso. Descobriram-se duas formas.

Em primeiro lugar, durante as pesquisas realizadas para elaborar este trabalho, percebeu-se que a doutrina frequentemente descreve o recesso como um instrumento de justiça, de equidade. Em tese, seu propósito é compensar a perda do poder de veto nas deliberações da assembleia geral, ou seja, o recesso serve de contrapeso para o princípio majoritário. Contudo, quando o valor pago ao minoritário não reflete sua participação na sociedade, esse caráter de equidade se perde, pois o acionista nem sequer cogita exercer o direito.

Se a lógica é preservar o respeito e os direitos dos acionistas minoritários, expôlos ao pagamento de um valor que é incompatível com sua participação na companhia equivale a minar seu senso de oportunidade para sair da empresa. Cria uma ilusão de escolha, que pode ser interpretada como um incentivo negativo para que o acionista permaneça na sociedade apesar das mudanças.

\footnotetext{
6 "The extant literature has raised but failed to resolve most of these issues. The first round of scholarly assault on the remedy noted the paucity of appraisal cases and railed against the remedy's cumbersome, technical and expensive process." Scholars argued that the many steps required to perfect appraisal rights, as well as high costs and expenses for attorneys and experts, greatly deterred utilization of the remedy." SIEGEL, op. cit., 1995, p. 79

${ }^{7}$ MYERS, Minor; KORSMO, Charles R. Appraisal Arbitrage and the Future of Public Company M\&A. Brooklyn Law School Legal School Legal Studies, 2014, p. 1553.
} 
O reembolso a um valor irrisório permite que se instale uma "tirania da maioria", parafraseando Manning, que realiza operações na companhia sem considerar a possibilidade de que um acionista solicite o reembolso.

Em segundo lugar, constatou-se que haver uma oportunidade de revisão do cálculo do valor das ações afeta diretamente os efeitos práticos do direito de recesso. Como se pôde observar, poder questionar o método de cálculo parece ser a chance de evitar uma dupla possibilidade de perda para o acionista minoritário. Partindo do pressuposto que este não acredita que a companhia conseguirá gerar valor para si pós-operação, é razoável supor que ele tentará evitar danos ao seu patrimônio. Contudo, se a legislação ou o estatuto da companhia não lhe garantem um valor justo, calculado a partir de um método que reflete a situação da companhia ao tempo da operação, o acionista terá que decidir entre perder com a modificação ou perder com o recesso e "pagar para sair".

De outra perspectiva, esse cenário é confortável para a companhia. Caso esteja em boas condições financeiras, a saída ou permanência do acionista não lhe afetará tanto. Trata-se, certamente, de uma descapitalização durante uma operação ou modificação no estatuto, contudo sua decisão não será necessariamente afetada pela saída do dissidente/ausente.

Estendendo o raciocínio desse segundo ponto, com o reembolso "a baixo custo" perde-se a oportunidade de resolver os problemas de agência, isto é, não há incentivo para a administração atender aos acionistas minoritários na melhor medida. A situação de dupla perda dos acionistas minoritários extingue ou diminui o risco de perda para a companhia. O acionista ou grupo majoritário pode elaborar e executar seus planos sem considerar os interesses dos acionistas minoritários, pois não haverá real interesse em sair, a não ser que a desvantagem seja demasiadamente relevante.

Como será visto, os destaques expostos acima destinam-se a demonstrar o potencial impacto que a mera consideração do valor justo como referencial para o cálculo do valor das ações modifica a distribuição de peso de barganha e rende ao recesso o potencial de atingir o propósito para o qual foi criado. 


\section{CONCLUSÃO}

No presente capítulo, far-se-á uma conclusão dos assuntos tratados, de forma a responder as perguntas propostas na introdução.

\section{A. QUAL A DEFINIÇÃO E OS PROPÓSITOS DO RECESSO?}

O recesso é um contrapeso ao princípio majoritário. Em troca de sujeitar-se às decisões da maioria, os acionistas minoritários guardam o direito de desligar-se da companhia, com o reembolso do valor de suas ações, para as decisões que modificam substancialmente a base do investimento.

O papel do recesso é ser uma ferramenta na proteção do acionista minoritário, tanto que foi incluído no rol dos direitos essenciais. Ele é uma válvula de escape para decisões delimitadas pela legislação que podem alterar principalmente as bases do investimento do acionista.

O recesso surte efeitos na companhia antes e depois da assembleia geral. Antes, a ameaça de descapitalização deveria fazer com que os controladores e a administração considerem os interesses dos minoritários ao propor operações das quais cabe o direito de recesso. A doutrina se refere à discrepância de vontades entre a administração e os minoritários como "problema de agência", o qual é resolvido quando a existência do recesso força a consideração dos interesses da minoria.

Depois da assembleia geral, os acionistas que não concorreram para a aprovação da pauta podem solicitar o recesso, o que lhes dá o direito de receber o valor de suas ações. Assim, o acionista resguardaria seu investimento antes de sofrer os efeitos da decisão.

É isso que o recesso deveria ser. Contudo a transferência da teoria para a realidade não é uma passagem tão tranquila, pois sua efetividade, enquanto proteção ao acionista minoritário, depende do impacto de um possível reembolso.

Na constância da elaboração deste trabalho, encontraram-se razões para crer que há um paradoxo intrínseco ao direito de recesso, mas que a chave para alcançar os propósitos do recesso é o reembolso a valor justo. Com base nessa conclusão, o recesso 
dificilmente será eficaz no Brasil, pois o critério de cálculo utilizado para avaliar a companhia, o patrimônio líquido contábil (na omissão do estatuto social), não considera bens imateriais, o goodwill ou a rentabilidade da companhia, de maneira que produz valores irrisórios. Assim, o desequilíbrio na aplicação fica evidente pois: (i) o impacto sobre a administração da companhia é mínimo, pois as chances de um acionista pedir o recesso são pequenas; (ii) o acionista minoritário dispõe apenas de uma ilusão de escolha entre ficar na companhia e suportar uma conjuntura que pode potencialmente lhe prejudicar ou sair e ser reembolsado em uma fração do que seu investimento representa; (iii) a companhia realiza o reembolso a um valor bem abaixo do de mercado e, dessa perspectiva, aufere um ganho.

Em suma, a resposta ao item está na influência do recesso sobre a dinâmica decisória da administração e os acionistas controladores da companhia. Entende-se que os dirigentes e os acionistas controladores ficarão mais motivados a gerar valor para os acionistas minoritários quando houver possibilidade de que a companhia tenha que arcar com o reembolso de acionistas insatisfeitos. Portanto o propósito do recesso tanto é ser uma oportunidade de saída para acionistas minoritários, como uma forma de solucionar os problemas de agência.

\section{B. POR QUE O RECESSO PERMANECE RELEVANTE HOJE?}

A resposta a esse item é de cunho prático, ou seja, qual o impacto da existência do recesso. Em poucas palavras, ele permanece relevante, pois é um instrumento de dinamização do mercado de ações e, para um país que almeja intensificar o volume e a frequência de trocas no mercado nacional, é essencial que ele esteja disponível e seja a preço justo.

Para chegar a essa conclusão, encontraram-se dois pressupostos fáticos.

Primeiro, entende-se que um investidor se sentirá mais motivado a adquirir ações que não possuem tanta liquidez e dispersão no mercado quando tiver à sua disposição outra forma de saída da companhia ao se alterarem as bases do investimento. $\mathrm{O}$ recesso seria essa alternativa, que supriria a ausência de mercado.

O segundo pressuposto fático é de que, no Brasil, o recesso não consegue efetivamente ser um instrumento de fomento para o mercado, porque o método de cálculo 
aplicado não proporciona um reembolso justo. Diferente do mercado de ações, que dispõe de analistas, o cálculo do reembolso não obedece a nenhum pressuposto lógico para ser aplicado, ele é fixo.

Para sustentar esse posicionamento, descobriu-se que os efeitos esperados do recesso podem ser observados em, pelo menos, dois países, os quais foram estudados no Capítulo 3.

No estado americano de Delaware, a legislação determina que os acionistas dissidentes recebam o "fair value" de suas ações. Isso quer dizer que, para cada caso, o magistrado tem que buscar a melhor evidência de valor justo da companhia.

Pode parecer que a ideia de acionistas exercendo o recesso a preço justo afastaria companhias do estado, contudo Delaware é justamente onde estão concentradas as sedes de mais da metade das corporations americanas, ou seja, a existência do recesso a preço justo para companhias que não se encaixam na "market-out exception" estimula investidores a buscarem essas companhias como forma de investimento.

$\mathrm{Na}$ Itália, por sua vez, expandiu-se o conceito de recesso para tornar a legislação atrativa para companhias no espaço europeu. Como é possível transferir a sede da companhia entre países, há concorrência entre as legislações.

Assim, em 2003, o ordenamento italiano passou por uma grande reforma e um dos institutos mais modificados foi o direito de recesso. O legislador italiano estendeu o conceito de "modificação profunda" para além de decisões da assembleia geral: agora, existem quatorze hipóteses de recesso. Mais importante que a inclusão de novas hipóteses, o reembolso foi de ser calculado pelo método de patrimônio líquido contábil para a média de seis meses dos preços de fechamento da cotação na bolsa, para sociedades abertas, e um conjunto de critérios a ser escolhido pela administração e ofertado aos acionistas minoritários, para sociedades fechadas.

Pode-se concluir, portanto, que há uma tendência em determinar o valor justo e assegurar que o reembolso seja, efetivamente, uma garantia para o acionista dissidente. 


\section{QUAIS OS CRITÉRIOS DE CÁLCULO DISPONÍVEIS E QUAL O MELHOR PARA EFEITOS DO EXERCÍCIO DO DIREITO DE RECESSO?}

Métodos de avaliação de empresas foram desenvolvidos para atingir fins não jurídicos. Eles são ferramentas que ajudam a gestão a tomar decisões e gerir a companhia. Nenhum deles tem o propósito de atingir o valor "real" da companhia; eles apenas revelam perspectivas diferentes da atividade empresarial.

Foram analisados cinco critérios de cálculo e seus métodos de cálculo respectivos.

O primeiro critério foi o patrimônio líquido. Os métodos de cálculo baseados nesse critério se destinam a avaliar os bens que uma companhia possui. Os analistas subtraem os passivos dos ativos.

A diferença entre os métodos é o que, exatamente, entra no cálculo como ativo. Para o patrimônio líquido contábil, método fixo na legislação atual, na omissão do estatuto social, contabiliza-se, apenas, o valor registrado de cada bem.

Com relação ao patrimônio líquido a preço de mercado, considera-se o valor de saída dos ativos da sociedade. Simula-se a venda de cada ativo como se fosse uma liquidação da companhia e divide-se esse valor pelo número de ações.

O patrimônio líquido contábil é um método clássico da contabilidade. Contudo não é refinado. Hoje, ele é usado para propósitos de gestão, de organização interna da companhia. Facilita a visualização de todos os ativos à disposição da realização da atividade empresarial, porém, não considera o valor do goodwill gerado pelos bens considerados em conjunto.

É difícil sustentar que o patrimônio líquido represente o valor da companhia, pois foi-se o tempo em que companhias acumulavam propriedades e bens como ativos principais. Por mais que esse perfil de companhia ainda exista, é possível observar que os tipos de companhia se diversificaram. Hoje, patentes, marca, know-how, clientela, posição de mercado e até modelo de negócios frequentemente têm mais relevância no patrimônio de uma empresa que bens materiais.

O segundo critério analisado foi o de preço de cotação de mercado. 
Com base nesse critério, a avaliação é feita a partir do comportamento dos compradores independentes e seus analistas. Observa-se quanto os agentes de mercado pagariam por um determinado valor de mercado. Isto é, observam-se os preços operados por um volume de agentes independentes para estimar o valor justo de uma ação da companhia.

A vantagem do valor de cotação na bolsa é que a companhia é avaliada por analistas que não estão, necessariamente, interessados em comprar. Eles divulgam o valor adequado para as ações para que sejam compradas por investidores.

É comum em outras legislações utilizar uma média dos preços de mercado por um período. Na jurisprudência americana, foi possível encontrar o período de 30 dias e, na italiana, a lei indica seis meses.

Quando tratamos de cotação de mercado, foi possível entender a opinião de estudiosos no sentido de argumentarem ser um dos métodos mais confiáveis para estimar o valor de uma companhia por conta da Hipótese de Mercado Eficiente. Trata-se de uma teoria da economia usada para monitorar o quando um determinado mercado age conforme as informações públicas e privadas sobre as companhias participantes. Basta que o mercado seja semiforte para ser considerado confiável, isto é, que reaja proporcionalmente às informações publicadas em livre acesso.

Porém nem sempre o mercado funciona de maneira racional. Bolhas, manipulação, vazamento de informações são eventos que podem afetar a confiabilidade de um mercado enquanto referencial para o preço de ações.

O terceiro critério, enquadrado neste grupo para efeito didático, é o preço negociado para a operação. Uma boa parte das hipóteses de recesso é de operações societárias - fusão, cisão, incorporação -, as quais demandam que a companhia seja avaliada. Assim, aproveita-se o valor já disponível. Ele representa, efetivamente, o preço que um comprador interessado pagaria pela companhia.

O quarto critério estudado foram estimativas de ganhos futuros.

Esse critério trata da rentabilidade projetada para uma determinada companhia. Observam-se as tendências de crescimento, de expansão e de mercado para determinar os possíveis retornos que a companhia apresentará. 
O método mais conhecido é o Fluxo de Caixa Descontado. O cálculo é feito por meio da projeção de caixa de uma companhia por um certo período e um desconto é aplicado para trazer o valor ao presente.

O cálculo envolve fazer algumas estimativas. Por exemplo, a tendência do fluxo de caixa da companhia, se irá crescer ou decrescer, o desconto a ser aplicado. Afinal, não se pode prever, com certeza, o futuro.

O último critério analisado é a comparação por múltiplos. Envolve a seleção de companhias semelhantes à alvo e o estabelecimento de critérios de comparação. Aproveitam-se os valores negociados para essas companhias para se estabelecer um valor aproximado.

O interessante desse método é que considera o contexto no qual a companhia está inserida, isto é, expande o olhar sobre o mercado para constatar a adequação do valor selecionado.

Qual desses métodos é o ideal para ser critério de avaliação das ações para fins de recesso? Nenhum desses métodos foi criado com tema pretensão de ser infalível. Os cinco critérios acima - patrimônio líquido, cotação de mercado, estimativa de rendimento, comparação por múltiplos e preço de negociação - são ideais em situações específicas e desvantajosos em outras. Não há um só que seja adequado para toda situação em um cenário.

\section{O QUE PODE SER APRENDIDO COM O DIREITO AMERICANO E QUAIS AS PRINCIPAIS FALHAS?}

Do estudo feito no direito americano, podem-se extrair algumas conclusões. A primeira é que não há método de cálculo perfeito. O importante, porém, não é encontrar o método perfeito e infalível, mas a melhor evidência de valor justo para cada situação. Em vez de selecionar um método único que funcione para todas as situações, o direito americano busca o melhor método para uma situação específica, considerando suas nuances e limitações.

A primeira vantagem que se pode apresentar é que o sistema permite que o acionista minoritário tenha mais chances de sair da companhia com um montante que 
reflete sua participação. Eleger um método apenas para ser aplicado sempre produz situações de evidente injustiça. Proceder assim é deixar de individualizar os pedidos de recesso e desconsiderar os fatos de cada caso.

A segunda vantagem seria que o procedimento americano tem mais chance de adaptar-se às mudanças no mercado, conforme os perfis da empresa.

Contudo existem desvantagens e falhas no direito americano.

A primeira deles é que o procedimento adotado pela Lei de Delaware permite o surgimento da indústria do recesso, algo que já foi resolvido pelo Brasil. A segunda falha é que a ação recesso custa caro, por vezes mais que o valor a ser restituído. A companhia oferta um valor quando anuncia a assembleia geral; se o acionista considerar que está sendo injustiçado, só pode pedir o recálculo por meio judicial, possibilitando inclusive que o requerente receba um valor menor do que lhe foi ofertado.

Observando os casos, é justo pontuar que deveria haver uma oportunidade de composição entre a companhia e os acionistas insatisfeitos. Fica a hipótese de que, se a legislação determinasse que houvesse tentativa de autocomposição, o processo seria mais justo para ambas as partes e o recesso poderia ser evitado.

Uma outra desvantagem é o conteúdo extrajurídico que o juiz precisa dominar para conseguir analisar cada um dos métodos de avaliação. A legislação exige que todos os métodos possíveis sejam levados em consideração e, para fazer esse juízo de valor, é necessário entender do assunto.

Por fim, em relação à jurisprudência, há dissenso entre o Tribunal de Delaware (primeiro grau de jurisdição) e a Suprema Corte (segundo grau de jurisdição) sobre como analisar os fatos para determinar qual a melhor evidência de valor justo. Isso gera insegurança para os acionistas e para as companhias, que precisam montar seus casos sem realmente compreender se estão em vantagem ou não.

\section{E. O QUE PODE SER APRENDIDO COM O DIREITO ITALIANO E QUAIS AS PRINCIPAIS FALHAS?}

De início, relembram-se dois aspectos do direito italiano quanto ao cálculo do valor do reembolso. 
Primeiro, para sociedades s.p.a. quotate (análogas à sociedade anônima aberta), o artigo 2437-ter determina que o reembolso será calculado a partir da média de preço de negociação no mercado nos seis meses antes da assembleia que ensejou o recesso. Esse método é fixo e não poder ser derrogado ou questionado.

Segundo, para sociedade s.p.a. non-quotate (análogas à sociedade anônima fechada), combina-se a "consistência patrimonial", a "perspectiva de performance de rendimentos" e o "valor de mercado das ações", se eventualmente existir. Tal sistema tem a vantagem de apontar várias perspectivas da companhia, sendo moldável ao caso concreto.

Essas duas formas de calcular o valor do reembolso provocam impactos diferentes na companhia.

O primeiro deles, para sociedades abertas. Adotar um método de cálculo fixo para determinar o valor das ações faz com que o reembolso nem sempre reflita o valor da companhia, pois nenhum método é infalível, principalmente quando se fala em valor de mercado. O mercado de ações está exposto a manipulações, bolhas e comportamento irracional dos agentes, de maneira que sua confiabilidade só pode ser verificada para um determinado momento, em relação a um determinado ativo ou classe de ativos. Há a possibilidade de determinar um método de cálculo diferente no estatuto social, porém é garantido aos acionistas pelo menos o valor de mercado, ou seja, há um piso legislativo para o valor das ações.

O segundo deles, para as companhias fechadas. Determina que a administração leve em consideração a consistência patrimonial da empresa, as perspectivas de rendimentos e o valor de mercado das ações, se houver, tendo, portanto, a vantagem de combinar os critérios para alcançar o valor mais próximo do real. Entretanto, a legislação italiana prevê a liberdade contratual para prever qualquer outro critério, o que poderia ofuscar o objetivo acima descrito. Em contrapartida, para evitar tais efeitos, existe previsão legal no sentido de que qualquer acordo que vise a excluir ou tornar excessivamente oneroso o exercício do direito de recesso é nulo. Em outras palavras, caso fosse adotado um método de cálculo que rendesse valores irrisórios, a previsão estatutária poderia ser declarada nula.

Podem-se tirar duas lições dessa metodologia do recesso. 
Primeiro, no caso das companhias abertas, pode ser perigoso fixar o recesso em apenas um método de cálculo, em vez de determinar um mecanismo para encontrar a melhor evidência do valor justo. Fixar um método de cálculo apenas pode não permitir que o recesso atinja os propósitos para os quais foi criado. Por exemplo, pode-se esperar uma época de desvalorização das ações para anunciar uma operação ou modificação no estatuto social. O impacto disso é que os acionistas continuam precisando ponderar sobre a conveniência do recesso, só que não mais pelo patrimônio, mas pelo desempenho no mercado. Já o segundo método, estabelecido para as companhias fechadas parece ser mais ponderado. Ele lista três perspectivas da companhia que devem ser levadas em consideração pela administração para gerar um valor que mais se aproxime com o valor real das ações.

A segunda lição que se pode notar é que a liberdade contratual plena para adotar um método de cálculo pode prejudicar o acionista. Poder-se-ia alegar que há um piso e uma determinação legal para garantir aplicação adequada, porém um piso representa apenas um mínimo, que pode ou não ser um valor justo. Em outras palavras, pautar-se pelo mínimo não equivale a buscar o justo ou o ideal.

Entende-se que há, neste ponto, uma falha no direito italiano. Existem razões para crer que ele funciona, afinal a reforma de 2003 elevou o recesso a um patamar de destaque na legislação. Contudo entende-se que não atingiu sua forma ideal quando não adota um mecanismo de busca do método ideal e permite a liberdade contratual quanto a esse ponto.

Por fim, importante verificar uma vantagem sutil com relação ao direito brasileiro, em relação às sociedades anônimas fechadas. $\mathrm{O}$ direito italiano estabelece a combinação de três critérios para determinar o valor de recesso, em caso de omissão do estatuto. Já o direito brasileiro, seguindo a posição dominante da doutrina, estabelece o valor patrimonial, no caso de omissão do estatuto social.

\section{F. QUAIS FALHAS PODEM SER OBSERVADAS NA LEGISLAÇÃO ATUAL?}

Com esse arcabouço teórico, é possível observar algumas falhas na redação do art. 45 da Lei das S.A., que disciplina o reembolso no Brasil. 
A primeira, e mais evidente, é que a redação é confusa. Em uma primeira leitura do art. 45, fica claro que a lei dá autonomia para que as companhias determinem o método de cálculo do reembolso em seus estatutos sociais, porém não torna essa escolha obrigatória. Já uma leitura mais atenta revela que a lei não necessariamente explica qual critério ou método de avaliação deve ser aplicado caso o estatuto seja omisso, podendo gerar controvérsias.

Contudo, a despeito dessa saga legislativa, dois casos julgados pelo Superior Tribunal de Justiça, contrariando a doutrina predominante, entenderam que, em caso de omissão do estatuto social, o critério de patrimônio líquido não deveria ser aplicado, pois os valores calculados para o reembolso eram irrisórios.

Uma outra falha é que, enquanto a lei não deixa explícito o método de cálculo a ser aplicado, ela deixa a critério das companhias a adoção de um.

O problema com isso é que a maior parte das companhias não menciona qual método usar em caso de reembolso. É contraditório que o recesso seja um direito essencial, que não pode ser revogado ou renunciado, mas o método de cálculo para efeito de reembolso possa ser escolhido pela companhia, que provavelmente escolheria um que produz valores mais baixos. Assim, mesmo que a lei previsse um método de cálculo que rendesse o valor justo ao reembolso, a companhia ainda poderia escolher outra. Por essa razão, não é razoável que a companhia tenha liberdade para escolher.

A maior falha da lei é não permitir que o reembolso seja individualizado para cada companhia. Nem sempre o valor mais adequado para estimar o valor de uma companhia é o mesmo para outra. Existem vários perfis e nem sempre o que vale para uma vale para outra. Dessa forma, o valor do reembolso pode ficar sobre avaliado, ou subavaliado. $\mathrm{O}$ que isso produz são situações em que a companhia ou o acionista minoritário sai com ganho.

Assim, por essas razões, considera-se que a redação atual da lei não é compatível com os propósitos para os quais o recesso foi criado, sendo necessário modificar a maneira como a companhia é avaliada.

Embora a doutrina majoritária concorde que o método de cálculo na omissão do estatuto é o patrimônio líquido, isso não quer dizer que concordem que esse é o melhor método de cálculo. 
Enfim, pelo fato de a redação do artigo 45 da Lei das S.A. ser confusa e de termos decisões confirmadas pelo Superior Tribunal de Justiça em sentido totalmente diverso à doutrina majoritária, já teríamos argumentos suficientes para uma mudança legislativa, o que nos leva ao ponto de examinar se realmente o artigo 45 da Lei das S.A. corresponde à realidade atual.

\section{G. A LEI ATUAL CORRESPONDE À REALIDADE?}

Com base em tudo que foi abordado neste trabalho, a resposta deve ser negativa.

Abordar-se-ão duas teses: primeiro, a evolução dos perfis das companhias e, segundo, a utilidade dos diferentes métodos de cálculo.

Em relação aos perfis das companhias, percebeu-se que o modo de operação e de registro do patrimônio das companhias mudou muito desde a última modificação no método de cálculo do recesso. Hoje, uma boa parte das companhias nem sequer é proprietária do espaço onde realiza sua atividade-fim e contrata companhias terceiras para realizar serviços de limpeza, manutenção e transporte, ou seja, apenas uma fração dos meios de produção realmente faz parte do patrimônio da companhia.

Isso afeta a maneira como esses itens são registrados no balanço contábil da companhia. Uma fração do que era registrada como ativo agora é registrada como passivo, o que afeta o cálculo do patrimônio líquido da companhia.

Além da evolução das companhias em si, as formas de estimar o valor das companhias também evoluiu ao longo dos anos. O mercado já adota, há décadas, a perspectiva do valor da perspectiva futura da companhia, isto é, o quanto a compra de uma determinada ação proporcionaria em lucro para um acionista, e é esse raciocínio que gera as negociações na bolsa. Não interessa para o acionista o que é de propriedade da companhia, mas o quanto ela consegue produzir.

Assim, existem métodos de cálculo cujo propósito é descobrir o valor da companhia em si, não de seus bens, pois é incoerente determinar o valor das ações sem considerar a companhia como um "going concern".

Partindo dessas teses, é justo concluir que, quando a lei determina que o reembolso seja calculado segundo o patrimônio líquido, mesmo que fosse a preço de mercado, ainda 
assim seria conceitualmente incoerente, pois a determinação legal estaria solicitando, em outras palavras, que o acionista comprasse a ação com base na rentabilidade, mas recebesse o patrimônio da companhia a título de recesso, coisa à qual nem sequer deveria ter acesso.

Conclui-se, pois, que há necessidade de atualizar a legislação, também, da perspectiva de que os operadores do Direito, que raciocinam segundo a hermenêutica jurídica, precisam estar conscientes de que a avaliação de companhias segue a lógica econômica. O impacto disso é que a legislação passará a atender seus propósitos na melhor medida possível, em vez de "esconder-se" detrás de convenções jurídicas.

\section{H. O RECESSO PELO VALOR JUSTO PODE INVIABILIZAR OPERAÇÕES?}

Poder-se-ia pensar que estabelecer o valor justo para o recesso inviabilizaria decisões importantes para a companhia. Entretanto, o fato de permitir que um acionista minoritário receba um valor justo quando exerça seu direito de recesso não pode ser visto como obstáculo para que a companhia possa atingir seu interesse social.

Na nossa visão, conforme dito anteriormente, basta ter as limitações ou efeitos corretos, em doses adequadas, para que isto não ocorra. Dentre elas, podemos citar: (i) as hipóteses que disparam o recesso devem ser taxativas e que mudem efetivamente a base do investimento ou a espinha dorsal do investimento feito pelo acionistas; (ii) somente pode exercer o recesso aquele que era acionista a época do anúncio, evitando o surgimento de fundos especializados em "appraisal arbitrage"; (iii) aquele acionista que exercer o direito de recesso deve ter consequências como, por exemplo, arcar com custos ou, quando o recesso for calculado a valor menor, ser reembolsado nesse valor, e não pelo previamente anunciado; (iv) deve-se buscar ter um sistema de autocomposição em que haja a possibilidade de solicitar nova avaliação por acionistas minoritários representantes de uma porção significativa do capital social, sem ter que recorrer diretamente ao judiciário; (v) embora apresente as suas ponderações, a regra do "market out exception" permite que o recesso para determinadas matérias somente possa ser exercido em companhias que não detenham liquidez e dispersão; e (vi) o recesso por valor que não seja irrisório produz um efeito automático na largada ex ante, isto é, a mera existência de 
um valor justo exerce o papel de incentivo para que a administração da companhia proponha uma operação que sejam vantajosa para todos os envolvidos.

Prova de que estabelecer um valor justo para o reembolso no recesso cria esse equilíbrio é que o número de operações nos Estados Unidos não tem decrescido, nem tem sido apontado pelas companhias como um obstáculo para a concretização de operações.

\section{QUAL É A PROPOSTA DE REFORMA PROPOSTA PARA O DIREITO DE RECESSO?}

Propôs-se, no presente trabalho, que o método de avaliação atualmente empregado para realizar oferta pública de aquisição para fechamento de capital deveria ser aplicado ao recesso, valendo, portanto, de uma interpretação sistemática da Lei das S.A. para alterar o art. 45.

Em primeiro lugar, porque os dois mecanismos são semelhantes: são oportunidades de saída, em razão da mudança das bases do investimento, nas quais a companhia paga aos acionistas o valor de suas ações.

Em segundo lugar, porque a companhia é avaliada pelo preço justo. De acordo com a Lei das S.A., para o caso de fechamento de capital, a companhia deve ser avaliada pelos critérios "de patrimônio líquido contábil, de patrimônio líquido avaliado a preço de mercado, de fluxo de caixa descontado, de comparação por múltiplos, de cotação das ações no mercado de valores mobiliários, ou com base em outro critério aceito pela Comissão de Valores Mobiliários”.

Observa-se, portanto, que esse método permitiria a individualização do reembolso para cada caso.

Em terceiro lugar, os acionistas podem questionar a escolha do método e o resultado do cálculo. Segundo o caput do art. $4^{\circ}$-A, os titulares de, no mínimo, $10 \%$ das ações em circulação do mercado podem solicitar aos administradores que convoquem assembleia especial dos acionistas para dispor sobre a contratação de outra companhia ou especialista para fazer outra avaliação. 
Dessa forma, o acionista não fica confinado a questionar que a data do balanço seja atualizada. Ele pode solicitar que o cálculo seja feito por outra empresa e pode, até mesmo, questionar o método de cálculo aplicado.

Em quarto lugar, caso haja concordância, a questão é resolvida interna corporis, sem necessidade de envolver o judiciário.

Como se viu, no estado de Delaware, pedir o recesso é sinônimo de iniciar um processo de "appraisal" para que um magistrado determine o "fair value" das ações. Isso gera custos adicionais à companhia e aos acionistas, tanto que o preço do procedimento foi apontado como um dos fatores que mais desestimulam os acionistas a exercerem o direito.

Assim, é melhor permitir que as partes tentem resolver a questão internamente que envolver uma autoridade sem que seja necessário. O procedimento para fechamento de capital faz exatamente isso.

Além disso, um juiz pode não ser o indivíduo ideal para tratar da questão. Uma boa parte das discussões no recesso é de natureza contábil, o que destoa do raciocínio jurídico. Portanto utilizar um método já testado na lei brasileira seria a melhor forma de tornar o direito de recesso um remédio efetivo para o acionista minoritário. 


\section{REFERÊNCIAS BIBLIOGRÁFICAS}

ACQUAS, Brunello; LECIS, Corrado. Il recesso del socio nella S.P.A. e nella S.R.L. Milão: Giuffrè, 2010.

ADAMEK, Marcelo Vieira von. Abuso de minoria em direito societário. São Paulo: Malheiros, 2014.

Responsabilidade civil dos administradores em S.A. (e as ações correlatas). São Paulo: Saraiva, 2009.

ALLRED, William S. Chipping Away at The Delaware Block: A Critique of the Delaware Block Approach to Valuation of Dissenters' Shares in Appraisal Proceedings. Western New England Law Review, Sss, n. 2, p. 191-227, jan. 1986.

AMARAL, Paulo Afonso de Sampaio. S.A. como era, como ficou após a Lei 9.457/97. São Paulo: Oliveira Mendes, 1998.

ARAGÃO, Paulo Cezar; SALLES, Denise C. Leão de. Uma leitura sistemática do artigo 256 da Lei das S.A. In: CASTRO, Rodrigo R. Monteiro de; ARAGÃO, Leandro Santos de. Direito Societário - desafios atuais. São Paulo: Quartier Latin, 2009.

; LIMA, Monique M. Mavignier de. Incorporação de controlada: a disciplina do art. 264 da Lei 6.404/76. In: PERIN JUNIOR, Ecio; KALANSKY, Daniel; PEYSER, Luis. Direito empresarial: aspectos atuais de direito empresarial brasileiro $e$ comparado. São Paulo: Método, 2005.

ASCARELLI, Tullio. Problemas das sociedades Anônimas e Direito Comparado. São Paulo: Quorum, 2008.

ASSAF NETO, Alexandre. Valuation: Métricas de Valor \& Avaliação de Empresas. São Paulo: Atlas, 2014.

AXELROD, Robert; HAMILTON, William D. The Evolution of Cooperation. Science, American Association For The Advancement Of Science, v. 221, p. 1390-1396, 27 mar. 1981. Disponível em: <http://links.jstor.org/sici?sici=00368075\%2819810327\%293\%3A211\%3A4489\%3C1390\%3ATEOC\%3E2.0.CO\%3B2-6>. Acesso em: 18 jun. 2019.

B3. Regulamento do Novo Mercado. São Paulo, 02 jan. 2018. Disponível em: $<$ http://www.b3.com.br/pt_br/regulacao/estrutura-normativa/listagem/>. Acesso em: 22 jan. 2020.

BALL, Ray. The Global Financial Crisis and the Efficient Market Hypothesis: What Have We Learned? Journal Of Applied Corporate Finance, Chicago, v. 2, n. 2, p. 01-27, 5 nov. 2009.

BERLE, Adolf A.; MEANS, Gardiner C. The modern corporation and private property. 1. ed. Transaction Publishers, 2009. 
BULGARELLI, Waldirio. O Direito de Recesso nas Hipóteses de Incorporação, Fusão, Cisão e Participação em Grupos de Sociedades. Exclusão acarretada pela Lei 7.958 de 20.12.89. Revista de Direito Mercantil, Industrial, Econômico e Financeiro, v. 95. São Paulo: Malheiros, 1994.

Regime Jurídico da Proteção às Minorias nas S/A (de acordo com a reforma da Lei $\mathrm{n}^{\circ}$ 6.404/76). Rio de Janeiro: Editora Renovar, 1998.

BRASIL. Décima Sexta Câmara Cível. Apelação no 30912-89/2011-0001. Apelantes: LAFARGE BRASIL LTDA e THIERRY APHREM MARIE GEORGES METRO. Recurso Adesivo: MARINGÁ S/A CIMENTO e FERRO LIGA e COMPANHIA DE CIMENTO PORTLAND PONTA ALTA. Relator: Relator: Des. Lindolpho Morais Marinho. Rio de Janeiro, RJ, 02 de dezembro de 2014. Apelação. Rio de Janeiro.

. Superior Tribunal de Justiça. Recurso Especial $n^{\circ}$ 1.572.648. Recorrente: LAFARGE BRASIL S/A. Recorrido: MARINGÁ S/A CIMENTO E FERRO-LIGA e COMPANHIA DE CIMENTO PORTLAND PONTE ALTA. Relator: Ministro Ricardo Villas Bôas Cueva. Recurso Especial. Brasília.

. Tribunal de Justiça de São Paulo. Ação Rescisória no 200656791.2015.8.26.0000. Acórdão. São Paulo.

Tribunal de Justiça do Estado do Rio de Janeiro. Apelação n. 30912- 89/20010001. 16 Câmara Cível. Relator: Desembargador Lindolpho Morais Marinho. Rio de Janeiro. j. em 02 dez. 2014.

Comissão de Valores Mobiliários. Processo Administrativo Sancionador RJ n. 2000/4912. Relator: Diretor Marcelo F. Trindade. Rio de Janeiro. J. em 2000.

Comissão de Valores Mobiliários. Processo Administrativo Sancionador RJ n. 2001/12133. Relator: Diretor Luiz Antônio de Sampaio Campos. Rio de Janeiro. J. em 2001.

Comissão de Valores Mobiliários. Processo Administrativo Sancionador n. 08/05. Relator: Diretor Eli Loria. Rio de Janeiro. J. em 2005.

Comissão de Valores Mobiliários. Processo Administrativo Sancionador n. 25/03. Relator: Presidente Maria Helena dos Santos Fernandes de Santana. Rio de Janeiro. J. em 2003.

CAMPINHO, Sérgio; PINTO, Mariana. O recesso na sociedade limitada. In: AZEVEDO, Luís André N. de Moura; CASTRO, Rodrigo R. Monteiro (coords.). Sociedade limitada contemporânea. São Paulo: Quartier Latin, 2013.

CAMPOBASSO, Gian Franco. Diritto Comerciale. 2. Diritto delle società. Turim: UTET Giuridica, 2015. 
CANARIS, Claus-Wilhelm. Pensamento Sistemático e Conceito de Sistema na Ciência do Direito. 5. ed. Lisboa: Fundação Calouste Gulbenkian, 2012.

CANTIDIANO, Luiz Leonardo. Análise crítica do Parecer de Orientação CVM 34. Revista de Direito Bancário e do Mercado de Capitais, ano 11, n. 41, São Paulo: RT, 2008.

CARVAlHOSA, Modesto. Comentários à Lei de Sociedades Anônimas. 6. ed. São Paulo: Saraiva, 2011.

; EIZIRIK, Nelson. A Nova Lei das S/A. São Paulo: Saraiva, 2002.

O direito de recesso e o inconstitucional artigo $3^{\circ}$ da Lei $\mathrm{n}^{\circ} 13.129$ de 2015.

Revista de Direito das Sociedades e dos Valores Mobiliários, v. 2, São Paulo: Almedina, 2015.

CASELTA, Lívia Garcia Kerr do Amaral. O Direito de Recesso nas Sociedades Anônimas. Dissertação (Mestrado). Universidade de São Paulo. 2016.

CESCHIN, Gisela. Direito de recesso na sociedade limitada e seus aspectos práticos. In: AZEVEDO, Luís André N. de Moura; CASTRO, Rodrigo R. Monteiro (coords.). Sociedade limitada contemporânea. São Paulo: Quartier Latin, 2013.

CHIAPPETTA, Francesco. Nuova disciplina del recesso di società di capitali: profili interpretativi e applicativi. Rivista Delle Società, anno 50, Milão: Giuffré, 2005.

CHOI, Albert H.; TALLEY, Eric L., Appraising the "Merger Price" Appraisal Rule, 35 J.L. Econ. \& Org. 543, 2019. https://clsbluesky.law.columbia.edu/2020/07/15/fir-tree-vjarden-and-ma-appraisal/ Acesso em: 20/07/2020.

CINTRA, Maria Lúcia de Araújo. Lei 7.958, de 20.12.89 (Lei Lobão). Revista de Direito Mercantil, Industrial, Econômico e Financeiro, n. 98, São Paulo: RT, 1995.

CLARK, Robert Charles. Corporate Law. Mount Vernon: Aspen Law \& Business, 1986.

COASE, Ronald Harry. The firm, the market and the law. Chicago: University Of Chicago Press, 1988.

COELHO, Fábio Ulhoa. Apuração de Haveres na Sociedade Limitada. In: YARSHELL, Flávio Luiz; PEREIRA, Guilherme Setoguti J. (Orgs.). Processo Societário. São Paulo: Quartier Latin do Brasil, 2012.

A ação de dissolução parcial da sociedade. Revista de Informação Legislativa, Brasília, ano 48, n. 190, p. 141-155, abr./jun.2011

CAMPOBASSO, Gian Franco. Manuale di diritto commerciale: La società. 6. ed. Roma: Utet Giuridica, 2016.

COMPARATO, Fábio Konder. Direito Empresarial. São Paulo: Saraiva, 1990. 
Ensaios e pareceres de direito empresarial. Rio de Janeiro: Forense, 1978.

. Novos ensaios e pareceres de direito empresarial. Rio de Janeiro: Forense, 1981.

; SALOMÃO FILHO, Calixto. O poder de controle na sociedade anônima. 6. ed. Rio de Janeiro: Forense, 2014. Atualização de Calixto Salomão Filho.

O Novo Direito de Retirada do Acionista nos casos de fusão e incorporação. Revista de Direito Mercantil, Industrial, Econômico e Financeiro, São Paulo, v. 116, p. 11-13, dez. 1999.

. Valor de reembolso no recesso acionário: Interpretação do art. 45 da Lei das sociedades por ações. Revista dos Tribunais, São Paulo, v. 3, n. 1846, p. 1177-1190, dez. 2010.

CORDEIRO. Antonio Menezes. Direito europeu das sociedades. Coimbra: Almedina, 2005.

CORRADINI, Luiz Eduardo Malta. Relação de substituição de ações em operações de incorporação e incorporação de ações. Dissertação (Mestrado) - Faculdade de Direito da Universidade de São Paulo, 2014.

CORRÊA, Rodrigo de Oliveira Botelho. Breves ponderações sobre o aparente conflito de normas que regem a substituição de acionistas dissidentes e reembolsados. Revista de Direito Mercantil, Industrial, Econômico e Financeiro, v. 131. São Paulo: Malheiros, 2003.

COZIAN, Maurice, VIANDIER, Alain; DEBOISSY, Florence. Droit des sociétés. Paris: Litec, 2006.

CRAVEIRO, Mariana Conti. Contratos entre sócios - Interpretação e direito societário. São Paulo: Quartier Latin, 2013.

CUNHA, Rodrigo Ferraz Pimenta. Estrutura de Interesses nas Sociedades Anônimas: Hierarquia e Conflitos. São Paulo: Quartier Latin, 2007.

CUNHA PEIXOTO, Carlos Fulgêncio. Sociedade por ações: comentários ao DecretoLei n. 2.627 de 26 de setembro de 1940, com as alterações da Lei n. 4.728, de 14 de julho de 1965, Lei de Mercado de Capitais. São Paulo: Saraiva, 1972. v. II.

Sociedade por ações: comentários ao Decreto-Lei n. 2.627, de 26 de setembro de 1940, com as alterações da Lei n. 4.728, de 14 de julho de 1965, Lei do Mercado de Capitais. São Paulo: Saraiva, 1973. v. III.

DAMODARAN, Aswath. Avaliação de Empresas. 2. ed. São Paulo: Pearson Prentice Hall, 2007. Revisão técnica de Mara Luquet.

Investment Valuation. 2. ed. Chicago: John Wiley \& Sons Ltd, 2002. 
DE LUCCA, Newton. O direito de recesso no direito brasileiro e na legislação comparada. Revista de Direito Mercantil Industrial, Econômico e Financeiro, n. 114, São Paulo: Malheiros, 1999.

DOTTO, Bruno Di. Negócios da companhia com ações de sua emissão. Dissertação (Mestrado) - Faculdade de Direito da Universidade de São Paulo, 2014.

EASTERBROOK, Frank H.; FISCHEL, Daniel R. The Corporate Contract. Columbia Law Review, Columbia, v. 1, n. 89, p. 1416-1440, jan. 1989.

Press, 1996. The Economic Structure of Corporate Law. First Harvard University

EIZIRIK, Nelson. A Lei das S/A Comentada. v. 1, 2 e 3. São Paulo: Quartier Latin, 2011. Reforma das S/A e do Mercado de Capitais. Rio de Janeiro: Renovar, 1998.

Reforma das S.A. e Direito de Recesso. In: Revista de Direito Mercantil, Industrial, Econômico e Financeiro, v. 111, São Paulo: Malheiros, 1998.

Direito Societário - estudos e pareceres. São Paulo: Quartier Latin, 2015.

Reforma da Lei das S.A. e o direito de recesso. In: LOBO, Jorge (coord.). A reforma da Lei das S.A. São Paulo: Atlas, 1998.

ESTADOS UNIDOS DA AMÉRICA. Sugestão Legislativa $\mathrm{n}^{\circ} 123$, de 2002. Model Business Corporation Act (MBCA). USA: Committee on Corporate Laws Of The Section Of Business Law Of The American Bar Association.

Suprema Corte do Estado de Delaware. Acórdão no 457 A.2d 701. Apelante: William B. WEINBERGER. Apelado: UOP, INC. Chief Justice HERRMANN.

Suprema Corte do Estado de Delaware. Acórdão no 518. Apelante: MUIRFIELD VALUE PARTNERS, L.P. e outros. Apelada: DFC Glob. Corp. Chief Justice STRINE. Acórdão. USA, 01 ago. 2017.

. Suprema Corte do Estado de Delaware. Acórdão n ${ }^{565}$. Apelante: MAGNETAR GLOBAL EVENT DRIVEN MASTER FUND LTD. e outros. Apelada: Dell INC. Relator: Chief Justice STRINE. Acórdão. Delaware.

. Suprema Corte do Estado de Delaware. Fir Tree v. Jarden, slip op., 2020 WL 3885166 (Del. July 9, 2020), Disponível em: https://courts.delaware.gov/Opinions/Download.aspx?id=307900

EFIGÉNIA, Ana Sílvia Falcão Mestre. O princípio "comply or explain" e a "soft law". Revista Electrónica de Direito do Centro de Investigação jurídico-econômica : Faculdade de Direito da Universidade do Porto, Fevereiro 2015, N. ${ }^{\circ} 1$. 
FAMÁ, Rubens; PEREZ, Marcelo Monteiro. Métodos de Avaliação de empresas e o balanço de determinação. Administração em Diálogo, São Paulo, v. 1, n. 6, p. 101-112, mar. 2004.

FERREIRA, Waldemar Martins. Tratado de Direito Comercial. v. 4. São Paulo: Saraiva, 1961.

FICO, Daniele. Lo scioglimento del rapporto societario. Recesso, esclusione e morte del socio. Milão: Giuffrè, 2007.

FISCHEL, Daniel R. The Appraisal Remedy in Corporate Law. American Bar Foundation Research Journal, Delaware, v. 01, n. 01, p. 875-902, jan. 1983.

FONSECA, Priscila Maria Pereira Corrêa da. Dissolução parcial, retirada e exclusão de sócio. 5. ed. São Paulo: Atlas, 2012.

FORGIONI, Paula Andréa. A evolução no direito comercial brasileiro: da mercancia ao mercado. São Paulo: RT, 2009.

; OCHMAN, Renato. Direito de retirada do acionista no fechamento de capital. Revista de Direito Mercantil Industrial, Econômico e Financeiro, v. 90, São Paulo: RT, 1993.

FRANÇA, Erasmo Valladão Azevedo e Novais. Conflito de Interesses nas Assembléias de S.A. (e outros escritos sobre conflito de interesses). 2. ed. São Paulo: Malheiros, 2014.

Invalidade das deliberações de assembleias das S.A. São Paulo: Malheiros, 1999.

Notas sobre a sociedade perpétua. Revista de Direito Mercantil, Industrial, Econômico e Financeiro, v. 157, São Paulo: Malheiros, 2011.

FRANCO, Vera Helena de Mello. A Correção Monetária no Valor de Reembolso do Recesso Societário. Revista de Direito Mercantil, Industrial, Econômico e Financeiro, v. 89, jan.-mar. 1993.

FREGONARA, Elena. Recesso e Procedimento per la liquidazione della azioni e delle quote. Milão: Giuffrè, 2008.

FRONTINI, Paulo Salvador, Sociedade anônima - direito de retirada - recesso de dissidente - Lei Lobão: um precedente judicial. Revista de Direito Mercantil, Industrial, Econômico e Financeiro, n. 86, São Paulo: RT, 1992.

GALGANO, Francesco. La forza del numero e la legge della ragione (Storia del principio di maggioranza). Bolonha: Il Mulino, 2007.

; GENGHINI, Ricardo. Il nuovo diritto societario. Padova: CEDAM - Casa Editrice Dott. Antonio Milani, 2006. t. I. 
GILSON, Ronald J.; HANSMANN, Henry; PARGENDLER, Mariana. Regulatory Dualism as a Development Strategy: Corporate Reform in Brazil, the United States, and the European Union. Stanford Law Review, Stanford, v. 63, n. 3, p. 475-537, mar. 2011.

Grupo de Trabalho Pratique ou Explique. Pesquisa Uso do Informe sobre o Código Brasileiro de Governança Corporativa - Companhias Abertas (2020), junho de 2020. Acesso em: 22/07/2020. Disponível em: https://conhecimento.ibgc.org.br/Paginas/Publicacao.aspx?PubId=24317

GUERREIRO, José Alexandre Tavares. Assembleia geral extraordinária de debêntures emissão - conversão em ações preferenciais com e sem direito a voto - direito de recesso dos acionistas minoritários. Revista de Direito Mercantil, Industrial, Econômico e Financeiro, n. 93, São Paulo: RT, 2009.

Direito das minorias na sociedade anônima. Revista de Direito Mercantil, Industrial, Econômico e Financeiro, n. 63, São Paulo: RT, 1986.

Direito de retirada: um limite ao princípio majoritário na sociedade anônima. Revista de Direito Mercantil, Industrial, Econômico e Financeiro, n. 151/152, São Paulo: RT, 2009.

Sociedade Anônima: dos sistemas e modelos ao pragmatismo. In: CASTRO, Rodrigo Monteiro de; AZEVEDO, Luís André N. de Moura (coord.). Poder de controle e outros temas de direito societário e mercado de capitais. São Paulo: Quartier Latin, 2010 .

Sociologia do poder na sociedade anônima. Revista de Direito Mercantil, Industrial, Econômico e Financeiro v. 29, n. 77, São Paulo: RT, 1990.

GRAU, Eros Roberto; FORGIONI, Paula Andréa. O Estado, a empresa e o contrato. São Paulo: Malheiros, 2005.

HENN, Harry G.; ALEXANDER, John R. Law of corporations. 3. ed. St. Paul: West Publishing Company, 1983.

INTERNATIONAL FINANCIAL REPORTING STANDARDS. IFRS 13: Fair Value Measurement. USA, 2012. 0101 p. Disponível em: <https://www.ifrs.org//media/feature/supporting-implementation/ifrs-13/education-ifrs-13-eng.pdf $>$. Acesso em: 06 jan. 2020.

IRTI, Natalino. Introduzione. Il dibattito sull'ordine giuridico del mercato. Roma: Laterza, 2003.

Persona e mercato. Rivista di Diritto Civile, Pádua: Casa Editrice Dott. Antonio Milani, ano 41, n. 3, 1995.

Teoria generale del diritto e problema del mercato. L'ordine giuridico del mercato. Roma: Laterza, 2003. 
IUDÍCIBUS, Sérgio de; MARTINS, Eliseu. Uma investigação e uma proposição sobre o conceito e o uso do valor justo. Revista Contabilidade \& Finanças - USP, São Paulo, v. 18, n. 1, p.9-18, jun. 2007.

JAEGER, Pier Giusto. L'interesse sociale. Milão: Dott. A. Giuffrè Editore, 1972.

KANDA, Hideki; LEVMORE, Saul. The appraisal remedy and the goals of corporate law. UCLA Law Review, Los Angeles, v. 32, n. 01, p. 429-473, jan. 1985.

KORSMO, Charles R.; MYERS, Minor. Appraisal Arbitrage and The Future of Public Company M\&A. Washington University Law Review, Washington, v. 92, n. 6, p. 15511615, jan. 2015.

KRAAKMAN, Reiner et al. The Anatomy of Corporate Law: A Comparative and functional Approach. 2. ed. New York: Oxford University Press, 2009.

KALANSKY, Daniel. Incorporação de ações - estudo de casos e precedentes. São Paulo: Saraiva, 2012.

KANDA, Hideki; LEVMORE, Saul. The Appraisal Remedy and the Goals of Corporate Law, 32 University of California, Los Angeles Law Review, 429, 1985.

KINDLER Peter; ROTH, Gunter H. The spirit of corporate law (Core Principles of Corporate Law in Continental Europe). C.H. Beck, Munique (copublicado pela Hart, Oxford, e Nomos, Baden-Baden), 2013.

LA PORTA, Rafael. LOPEZ-DE-SILANES, Florencio; SHLEIFER, Andrei; VISHNY, Robert W. Legal Determinants of External Finance. Journal of The American Finance Association, 2012.

LAMY FILHO, Alfredo; PEDREIRA, José Luiz Bulhões. A Lei das S/A. v. I e II. Rio de Janeiro: Renovar, 1996.

; __ Direito das Companhias. 2. ed. Rio de Janeiro: Forense, 2017. Atualizada e reformulada.

LAZZARESCHI NETO, Alfredo Sérgio. Lei das sociedades por ações anotada. 5. ed. São Paulo: Societatis Edições, 2017. Revista, atualizada e ampliada.

LETSOU, Peter V. The Role of Appraisal in Corporate Law, 39 B.C.L. Rev. 1121 (1998).

LEÃES, Luiz Gastão Paes de Barros. Pareceres. v. II. São Paulo: Singular, 2004.

LO CASCIO, Giovanni; PROTO, Cesare; PLATANIA, Anna Giulia; PLATANIA, Fernando. Società per azioni. Obligatizioni, deposito, iscrizione e publicazione delle modificazioni, recesso, operazioni sul capitale. 2. ed. Milão: Giuffrè, 2007.

LOBO, Jorge. Direito de retirada nos casos de fusão, incorporação, cisão e participação em grupos de sociedades. RT 664, 1991. 
LUCENA, José Waldecy. Das Sociedades Anônimas: Comentários à lei (arts. $1^{\text {o a }}$ 120). Rio de Janeiro: Renovar, 2009. v. II.

Das sociedades por quotas de responsabilidade limitada. 2. ed. Rio de Janeiro: Renovar, 1997.

LUZIO, Eduardo. Fusões e aquisiç̃̃es em ato: Guia prático: geração e destruição de valor em M\&A. Rio de Janeiro: Editora Senac, 2014.

MACHADO, Rubens Approbato. Sociedade Por Ações - Incorporação, Fusão e Cisão Direito de Retirada. Revista de Direito Mercantil, Industrial, Econômico e Financeiro, v. 82. abr.-jun. 1986.

MACEY, Jonathan; MITTS, Joshua. Asking the Right Question: The Statutory Right of Appraisal and Efficient Markets. ECGI Working Paper Series In Law, LA, v. 01, n. 01, p.01-61, dez. 2018, n. 428/2018.

MAHONEY, Paul; WEINSTEIN, Mark. The appraisal remedy and merger premiums. American Law and Economics Review, v. 1, n. 1/2 (Fall 1999), pp. 239-275.

MÁlAGA, Flávio Kezam. Análise de demonstrativos financeiros e da performance empresarial: para empresas não financeiras. 2. ed. São Paulo: Saint Paul, 2012.

MANNING, Bayless. The shareholder's appraisal remedy: An essay for Frank Coker. The Yale Law Journal, New Haven, v. 72, n. 2, p. 224-264, dez. 1962.

MARANGONI, Sérgio Ricardo Nutti. Direito de Recesso e respectivo valor de reembolso em companhias. 2015. 159 f. Dissertação (Mestrado) - Curso de Direito, Escola de Direito de São Paulo, Fundação Getúlio Vargas (FGV), São Paulo, 2015.

MARQUES, Evy Cynthia. O direito de retirada de sócios de sociedade simples e sociedade limitada. Dissertação (Mestrado) - Faculdade de Direito da Universidade de São Paulo, 2010.

MARTINS, Eliseu. Avaliação de Empresas: da Mensuração Contábil à Econômica. São Paulo: Atlas, 2014.

MARTINS, Fran. Comentários à Lei das Sociedades Anônimas: Artigo por Artigo. 4. ed. Rio de Janeiro: Forense, 2010. Revista e atualizada por Roberto Papini.

. Novos estudos de direito societário. São Paulo: Saraiva: 1988.

MAXIMILIANO, Carlos. Hermenêutica e aplicação do Direito. 20. ed. Rio de Janeiro: Forense, 2011.

MENDONÇA, José Xavier Carvalho de. Tratado de direito comercial brasileiro. 2. ed. Rio de Janeiro: Livraria Editora Freitas Bastos, 1933. 
MENEZES, Paulo Lucena de. A disciplina de Recesso no Projeto de Lei n. 1.564/96. Revista de Direito Mercantil Industrial Econômico e Financeiro, n. 105, São Paulo: Malheiros, 1997.

MILONE, Mario César de Mattos. Cálculo do valor de Ativos Intangíveis: Uma metodologia alternativa para a Mensuração do valor de marcas. 2004. $142 \mathrm{f}$. Tese (Doutorado) - Curso de Faculdade de Economia, Administração e Contabilidade, Departamento de Administração, Universidade de São Paulo, São Paulo, 2004. Disponível em: <https://teses.usp.br/teses/disponiveis/12/12139/tde-27122005214349/publico/TeseDout_MarioMilone_1204.pdf>. Acesso em: 08 nov. 2019.

MORITZ, Renata Brandão. As Hipóteses de Recesso na Lei das Sociedades Anônimas. Revista de Direito Mercantil, Industrial, Econômico e Financeiro, v. 101, ano XXXV, jan./mar. 1996.

MUNHOZ, Eduardo Secchi. Aquisição de controle na sociedade anônima. São Paulo: Saraiva, 2013.

Transferência de controle nas companhias sem controlador majoritário. In: CASTRO, Rodrigo Monteiro de; AZEVEDO, Luís Andre de Moura (coord.). Poder de controle e outros temas de direito societário e mercado de capitais. São Paulo: Quartier Latin, 2010.

MUSNICH, Francisco Antunes Maciel. Reflexões sobre o Direito de Recesso na Lei de Sociedade por Ações. In: LOBO, Jorge (coord.). Reforma da Lei das Sociedades Anônimas. Rio de Janeiro: Forense, 2002.

MYERS, Minor; KORSMO, Charles R. Appraisal Arbitrage and the Future of Public Company M\&A. Brooklyn Law School Legal School Legal Studies, 2014.

NAKAMURA, Angela Mie. Avaliações de participações societárias: estudo dos critérios contábeis aplicáveis à sua transação e considerações sobre seu valor justo. Dissertação (Mestrado) - Faculdade de Economia, Administração e Contabilidade. Universidade de São Paulo, São Paulo, 1987.

NANNI, Giovanni Ettore. Enriquecimento sem causa. 3. ed. São Paulo: Saraiva, 2012.

NEIVA, Raimundo Alelaf. Valor de Mercado da Empresa. São Paulo: Atlas, 1992.

NUNES, Marcelo Guedes. O direito de recesso nas incorporações. In: CASTRO, Rodrigo R. Monteiro de: ARAGÃO, Leandro Santos de. Reorganização societária. São Paulo: Quartier Latin, 2005.

OIOLI, Erik Frederico; VEIGA, Marcelo Godke. Convergência e divergência em sistemas de mercados de capitais: o caso brasileiro. In: CASTRO, Rodrigo Monteiro de; AZEVEDO, Luís André N. de Moura (coord.). Poder de controle e outros temas de direito societário e mercado de capitais. São Paulo: Quartier Latin, 2010.

OLIVERIA, Ary Brandão de. O direito de recesso nas sociedades por ações. Dissertação (Mestrado) - Faculdade de Direito da Universidade de São Paulo, 1983. 
PARAÍSO, Anna Luiza Prisco. O Direito de Retirada na Sociedade Anônima. 2. ed. Rio de Janeiro: Lumen Juris, 2000.

PARENTE, Norma Jonssen. O Direito de Recesso na incorporação, fusão ou cisão de sociedades. Revista de Direito Mercantil, Industrial, Econômico e Financeiro, São Paulo, v. 97, n. , p. 67-75, jan. 1995.

Principais inovações introduzidas pela lei $\mathrm{n}^{\circ} 10.303$, de 31 de outubro de 2001, à lei de sociedades por ações. In: LOBO, Jorge (Coord.). Reforma da lei das sociedades anônimas - inovações e questões controvertidas da lei $\mathrm{n}^{\circ} 10.303$, de 31 de outubro de 2001. 2. ed. Rio de Janeiro: Forense, 2002.

PENTEADO, Mauro Rodrigues. A Lei 7.958/89 e pretensa modificação do direito de retirada dos acionistas: uma discussão inócua. Revista de Direito Mercantil, Industrial, Econômico e Financeiro, n. 77, São Paulo: RT, 1990.

. Dissolução e Liquidação de Sociedades. Brasília: Brasília Jurídica, 1995.

p. 24, 1992.

Lei Lobão. Minoritários sem vez. Revista ABAMEC, Divulgação Nacional, v. 1,

O direito de retirada dos acionistas na Lei 9.457/97. In: LOBO, Jorge. A reforma da Lei das S.A. São Paulo: Atlas, 1998.

PEREIRA, Caio Mario da Silva. Instituições de direito civil - Introdução ao direito civil, teoria geral do direito civil. 21. ed. Rio de Janeiro: Forense, 2005. v. I.

PONTES DE MIRANDA, Francisco Cavalcanti. Tratado de direito privado - direito das obrigações. Rio de Janeiro: Forense, 1953. v. L.

Tratado de direito privado. Parte especial. 3. ed. Rio de Janeiro: Borsoi, 1972. T.

L.

PRADO, Roberta Nioac; VILELA, Renato. Sair por Quanto? Adequação do Método de Avaliação de Participação Societária em Dissolução Parcial de Sociedade. In: AZEVEDO, Luís André N. de Moura; CASTRO, Rodrigo R. Monteiro de (coord.). Sociedade Limitada Contemporânea. São Paulo: Quartier Latin, 2013.

PRADO, Viviane Muller. Interpretação da regra de conflito de interesses nos grupos societários de fato conforme a Lei 6.404/76. Tese (Doutorado) - Faculdade de Direito da Universidade de São Paulo, 2004.

PRISCOLLI, Lorenzo Delli. Delle modificazioni dello statuto - Diritto di recesso Art. 2437-3437 - sexies - II Codice Civile Comentário. Milão: Giuffrè, 2013.

REBOA, Marco. Criteri di stima delle azioni in caso di recesso del socio: alcune riflessioni sull'art. 2437-Ter C.C. Rivista Dei Dottori Commercialisti, Milão, v. 1, n. 1, p. 907-926, maio 2008 . 
RETTO, Marcel Gomes Bragança. Direito de Recesso e as Alterações Introduzidas pelas Leis n. 9457/1997 e 10.303/2001. Revista de Direito Mercantil, Industrial, Econômico e Financeiro. v. 147, jan.-set., 2007.

RIPERT, Georges. Traité élémentaire de droit commercial. 12 ed. Paris: Librarie Générale de Droit et de Jurisprudence, 1986.

ROBERT, Bruno. Dissolução entre o exercício do direito de voto e o estado de sócio no mercado de capitais contemporâneo. In: FRANÇA, Erasmo Valladão Azevedo e Novaes (coord.). Direito societário contemporâneo II. São Paulo: Malheiros, 2015.

SALAMA, Bruno Meyerhof (org.). Apresentação. Direito e Economia. Textos Escolhidos. Série Direito em Debate. Direito Desenvolvimento Justiça. São Paulo: Saraiva, 2010.

O que é Pesquisa em Direito e Economia. Extraído do "bepress" do autor e com sua prévia autorização.

A História do Declínio e Queda do Eficientismo na Obra de Richard Posner. Extraído do "bepress" do autor e com sua prévia autorização. Texto de 19 ago. 2010.

SALOMÃO FILHO, Calixto. O Novo Direito Societário. 2. ed. São Paulo: Malheiros, 2002.

SCHMIDLIN, Nicolas. The Art of Company Valuation and Financial Statement Analysis: A Value Investor's Guide with Real-life Case Studies. West Sussex: John Wiley \& Sons Ltd, 2014.

SCHMIDT, Dominique. Les droits de la minorité dans la société anonyme. Paris: Librairie Sirei, 1970.

SELIGMAN, Joel. Reappraising the Appraisal Remedy. George Washington Law Review, Arlington, v. 52, n. 01, p. 829-871, jan. 1984.

SIEGEL, Mary. Back to the future: Appraisal Rights in the twenty-first century. Harvard Journal On Legislation, Cambridge, v. 01, n. 32, p. 79-143, 1995.

SHILLER, Robert J. Irrational Exuberance (3rd ed.). Princeton, NJ: Princeton University Press, (2015) [2000].

SOLOMON, Lewis D.; SCHWARTZ, Donald E.; BAUMAN, Jeffrey D.; WEISS, Elliot J. Corporations Law and Policy: material and problems. 3. ed. St. Paul: West Publishing Co., 1994.

SOUZA JUNIOR, Francisco Satiro de. Dissolução de sociedades anônimas. In: FINKELSTEIN, Maria E. R.; PROENÇA, José Marcelo Martins (orgs.). Direito Societário - gestão e controle. São Paulo: Saraiva, 2008.

SZTAJN, Rachel. Conceitos de Liquidez na disciplina do mercado de valores mobiliários. Revista de Direito Mercantil, Industrial, Econômico e Financeiro, v. 126, São Paulo: Malheiros, 2002. 
Direito de Recesso. 1982. 312 f. Tese (Doutorado) - Curso de Direito, Departamento de Direito Comercial, Universidade de São Paulo, São Paulo, 1982.

O direito de recesso nas sociedades comerciais. Revista de Direito Mercantil, Industrial, Econômico e Financeiro, n. 71, São Paulo: RT, 1988.

TEIXEIRA, Egberto Lacerda; GUERREIRO, José Alexandre Tavares. Das Sociedades Anônimas no Direito Brasileiro. v. 1. São Paulo: José Bushatsky, 1979.

TOMAZETTE. Marlon. Liberdades de associação e o recesso nas sociedades limitadas. Revista de Direito Brasileira, v. 1, n. 1, 2011.

VALVERDE, Trajano de Miranda. Sociedades por Ações. v. 1. Rio de Janeiro: Forense, 1959.

VENTORUZZO, Marco. Cross-Border Mergers, Change of Applicable Corporate Laws and Protection of Dissenting Shareholders: Withdrawal Rights under Italian Law. European Company and Financial Law Review, Chicago, v. 1, n. 4, p. 47-75, abr. 2007.

I criteri di valutazione delle azioni in caso di recesso del socio. Rivista Delle Societa', Roma, v. 1, n. 1, p. 310-458, 2005.

VERÇOSA, Haroldo Malheiros Duclerc. Direito Comercial Vol. 1, 2 e 3. São Paulo: Revista dos Tribunais - RT, 2013.

Direito de retirada: tratamento legal na falência e na recuperação. Hipóteses de suspensão, possibilidade, ou não, de eliminação do direito de retirada. In: CASTRO, Rodrigo R. Monteiro de; ARAGÃO, Leandro Santos (orgs.). Direito societário e a Nova Lei de Falências e Recuperação de Empresas. São Paulo: Quartier Latin, 2006.

VIEIRA, Maíra de Melo. Dissolução parcial de sociedade anônima - construção e consolidação no direito brasileiro. São Paulo: Quartier Latin, 2014.

VIVANTE, Cesare. Trattato di diritto commerciale. 4. ed. Milão: Casa Editrice Dottor Francesco Vallardi, 1912.

WAH, Janice Chin Poh. Improving Corporate Governance in China through Differentiated Listing Segments: Lessons from the Brazilian Novo Mercado. City University of Hong Kong Law Review, Hong Kong, v. 3, n. 1, p. 141-162, jan. 2011.

WALD, Arnold. Comentários ao Novo Código Civil - Livro II - Do direito da empresa. Coord. Sálvio de Figueiredo Teixeira. Rio de Janeiro: Forense, 2005.

Os Bancos Múltiplos e o Direito de Recesso. Revista de Direito Mercantil, Industrial, Econômico e Financeiro, v. 87, São Paulo: Malheiros, jul./set. 1992.

Término de concessão e direito de recesso. Revista de Direito Mercantil, Industrial, Econômico e Financeiro, v. 40, São Paulo: RT, 1980. 